\title{
Language Contact and Lexical Changes in Khmer and Teochew in Cambodia and Beyond
}

\author{
Joanna Rose McFarland
}

Chinese people have formed vibrant communities throughout Southeast Asia and around the world, in which their culture and language are still very much alive today. One example of this is the Teochew people, who originated from the Chaoshan (潮汕; Chaozhou-Shantou) region of eastern Guangdong. From the eighteenth to the twentieth centuries, many Teochew people emigrated from China around Southeast Asia, including to Cambodia, Indonesia, Malaysia, Singapore, Thailand, and Vietnam. Teochew (潮州; also called Chaozhou, Chiuchow, Swatow, or Teochiu) is a member of the Sinitic Southern Min cluster and varieties in and out of China have been featured in several studies over the years. This research is explored below. Yet the available literature is still lacking. This is especially true for the Teochew of Cambodia, where the group makes up an abundant majority of the ethnic Chinese there, having resided in the country for several generations. Despite governmental oppression of these peoples during the 1970s and 1980s, many Cambodian Chinese continued speaking their native Sinitic languages and passed them on to the next generations, albeit with some changes. Continued contact with Khmer, the official language of Cambodia, has created an environment conducive to language change. Thus, when comparing Teochew varieties, we should expect Cambodian Teochew to have some differences in its sound system (phonology), grammar (syntax), and vocabulary (lexicon). This chapter

1 This chapter represents a portion of the researcher's work on creating a comprehensive reference grammar of Cambodian Teochew. For additional comparisons between Cambodian Teochew and the varieties spoken in Chaoshan and Southeast Asia, including phonological and grammatical divergences, see McFarland (forthcoming). Throughout this chapter, Chinese characters have been converted to simplified Chinese in accordance with contemporary Cambodian preferences, including those of the consultants in this study. 
focuses on the lexical differences by highlighting Khmer loanwords that are unique to the vocabulary of the Cambodian Teochew variety. ${ }^{2}$

The earliest works on Teochew come from foreign missionaries to China and include dictionaries (Duffus 1883; Fielde 1883; Goddard 1888) and phrasebooks (Ashmore 1884; Dean 1841; Fielde 1878; Giles 1877; Lim 1886). In recent times, scholars have looked at Chaoshan varieties of Teochew from both phonetic/phonological (Bao 1999; Hong 2013; Li 2014; Lin 1995; Lin \& Chen 2011; Lin 2019; Xu 2016) and syntactic (Matthews, Xu, \& Yip 2005; Matthews \& Yip 2008; Xu \& Matthews 2011, 2013) viewpoints. For more comprehensive sources, $\mathrm{Li}$ (1959) and Xu (2007) provided full and partial, respectively, grammars of the Jieyang 揭阳 variety and highlighted some of the ways in which Teochew differs from Mandarin and other Sinitic languages. Lin Lunlun (1996) looked at the Chenghai 澄海 variety, also making comparisons to Mandarin and Middle Chinese.

Aside from varieties spoken in China, Low (2014) and Yeo (2011) presented grammatical sketches of Singapore Teochew that covered detailed phonology, the structure of noun and verb phrases, interrogative sentences, particles, and more. Low additionally provided a short list of Malay and English loanwords found in Singapore Teochew. While neither source offered a comprehensive grammar, both projects provided good basic data on the language variety. Goh (2017) created a dictionary of words and phrases used in everyday Singapore Teochew. Also included was a separate list of Singapore Teochew terms that have been borrowed from languages such as English and Malay. Li (1991) outlined the sound system of Singapore Teochew and presented a list of 100+ loanwords from English and Malay. Additionally, Li provided 50+ "special words" that arose from the influence from Hokkien and other Sinitic languages spoken in Singapore. From a formal syntactic standpoint, Cole and Lee (1997) looked at yes/no question formation while Cole Hermon, and Lee (2001) explored long distance reflexives in Singapore Teochew.

Next door, in Malaysia, Khoo Kiak Uie studied tonal differences (2017b), phonetic variation such as vowel nasalization and word onset alternations (2017a), and dialect mixing and a unique tone phenomenon (2018) of Teochew fishing villages in North Perak, Selangor, and Parit Jawa respectively.

On varieties spoken in Indonesia, Peng's (2012) doctoral dissertation studied syntactic constructions in Jambi Teochew and Pontianak Teochew that

2 While I use the term "Cambodian Teochew" to refer to the variety of Teochew spoken by Cambodian Teochew people, it is likely that there is variation amongst Teochew speakers in different regions of Cambodia, as Peng (2012) found in Indonesia with the Jambi and Pontianak varieties (see below). 
differed from those in Jieyang, citing contact with Malay as a reason for the divergences. Focusing on relative clauses, Peng (2011) found that Jambi Teochew displayed both head-final (characteristic of Chinese languages) and head-initial (characteristic of Malay languages) word orders. Relative clauses also optionally borrow the Malay relativizer yang. Peng's (2012) main consultant for her Pontianak Teochew data was Yohana Veniranda, who herself studied Pontianak Teochew, specifically focusing on perfective aspect and negative markers and their interaction (Veniranda 2015), as well as acoustic differences between oral and nasal vowels and diphthongs (Veniranda 2016).

In Thailand, Atchariyasucha (1982) explored the phonology of Teochew in detail based on 1,280 words collected from one consultant, and made comparisons to the Thai sound system. Eiampailin (2004) worked with twelve native speakers of Teochew living in Bangkok who spoke Thai as a second language to study the phonological interference of Teochew on the speakers' Thai. Eiampailin's research included basic phonology of the target language based on the speech of the 12 consultants, which was largely identical to Atchariyasucha (1982) with some speaker variation in vowel nasalization. Other work includes that of Phadungsrisavas (2008), who compared the tone and tone sandhi systems of 20 speakers from five regions of Thailand, and Lin (2006), who examined Teochew loanwords in Thai and Thai loanwords in Teochew.

Chen (2009) explored the vernacular reading of Chinese texts by the Teochew in Cambodia, Laos, and Vietnam. The work included a brief outline of the phonology of each variety. Interestingly, the author noted the existence of initial /f/ in the Teochew of the Laotians and Vietnamese which I have not found written about in any other Teochew varieties.

As for Cambodia, in addition to Chen's (2009) introduction to the sounds of Cambodian Teochew, Pan (2000) showcased the pronunciation, vocabulary, and grammar of a third-generation Cambodian Teochew whose ancestors were from Jieyang. While the paper amounts to just eight pages and is only based on one speaker (with the pronunciation compared to one other), the research marks a good starting point for the documentation of Cambodian Teochew, even highlighting some divergences from other Teochew varieties such as vowel nasalization and the use of negation.

Overall, the body of research on Teochew is lacking, particularly for varieties outside of the Chaoshan region. This is unfortunate given the unique phenomena that were highlighted in the previous sources such as localized loanwords (Goh 2017; Li 1991; Lin 2006; Low 2014), and varietal phonological (Chen 2009; Khoo 2017a, 2017b, 2018; Pan 2000) and grammatical (Peng 2011, 2012; Pan 200o) divergences. This chapter, as well as McFarland (forthcoming), aims to bridge some of this gap by contributing novel work to the fields of Sinitic and 
Cambodian linguistics, as well as to the field of contact linguistics, hopefully shedding light on the behaviour of languages in contact environments.

A few different romanization systems have historically been used for Teochew. The Peh-oē-jī system, or "Church Romanization", was created in the nineteenth century by Western missionaries for writing all Sinitic Southern Min varieties. In 1960, the provincial government of Guangdong, China created a system known as the "Teochew Transliteration Scheme" or Peng'im, which is a Teochew transliteration of Mandarin pinyin 拼音. In 2002, language enthusiasts from the organization Gaginang 家己人 'our own people' began developing the Gaginang Peng-im System (GPIRS), which is an adaptation of Guangdong's Peng'im (TCKnow LLC. 2015). No speaker interviewed for this project wrote using one of these romanization schemes. Instead, when messaging friends or family, they would write in Khmer, Mandarin, or English, or send a voice recording in Teochew. ${ }^{3}$

Given my speakers' non-usage of romanization schemes, throughout this chapter, the collected data on Cambodian Teochew is presented in the International Phonetic Alphabet (IPA). Tone is indicated by numerical superscripts which represent the approximate pitch level of the voice on a fivepoint scale with [1] representing the low point and [5] the high point. When comparing data from the literature on Khmer and other Teochew varieties, words have been converted to the IPA for consistency. When not explicitly provided, tone pitch values have been approximated from tone markings in the original source.

The rest of the chapter is organized as follows: section 2 provides historical context for the Chinese in Cambodia before detailing their sociolinguistic situation as compared to Teochews in other parts of Southeast Asia, while also covering the Sinitic influence on Khmer, Thai, and Lao vocabulary; section 3 details the methodology for the present study and the findings and makes comparisons to other findings on loanwords in the world's languages; section 4 offers limitations to the current research, areas for future study, as well as some concluding remarks.

3 Low (2014) noted that the romanization schemes are also not used in Singapore. It has been shown that Indonesian Teochew people do transliterate Teochew in online spaces (see Birnie-Smith 2016). 
This section provides background information on the ethnic Chinese in Cambodia and their sociolinguistic situation and makes comparisons to Teochews in other parts of Southeast Asia. It also showcases some of the Chinese loanwords found in the languages of the region including Khmer and Thai.

\subsection{Note on Terminology}

There are several terms in the Khmer language to describe ethnic Chinese people. ${ }^{4}$ Those who were born in China and emigrated to Cambodia are referred to as $c ə n c^{h} a v$ ธิsรฐา, directly translated as 'raw Chinese'. Their descendants are known as cən ธิฐ 'Chinese', kooncən กู่ธิธิs, literally 'children of Chinese' but also used to mean 'Cambodian Chinese', or kooncavcวn กูรเษไิิ 'grandchildren of Chinese'. Those from mixed families can be described as

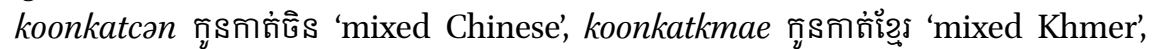
or kmaekatcวn โ่อุกกต่ษิs 'mixed Khmer-Chinese', where kat translates to 'cut', suggesting a cut or split heritage. Recent Chinese immigrants from mainland China are known as cəndaekook ธิ ธิธีธกิก 'mainland Chinese'. Finally, cantiiaciiw ธิ§ษานีร 'Teochew' refers specifically to those with Teochew heritage.

As for Teochew terms, $h u a^{11} d z i \eta^{24}$ 华人 'Chinese' can be used for all ethnic Chinese and $h u a^{11} k^{h} i a u^{55}$ 华侨 'Overseas Chinese' historically referred to Chinese citizens abroad. Nowadays it may be used for some speakers who do not have Chinese nationality. Hua ${ }^{11} i^{24}$ 华裔 'Overseas Chinese' is a term used for people of Chinese heritage with citizenship from another country. Most Cambodian Chinese are technically $h u a^{11} i^{24}$, though my consultants reported unfamiliarity with the term, or rarely using it. The word $t a \eta^{11} n a \eta^{55}$ 唐人 'Chinese', or people from the Tang 唐 Dynasty, is also used to mean 'Overseas Chinese'. Some Teochews in Cambodia use $\operatorname{ta\eta }^{11}$ na $^{55}$ to refer specifically to Teochew people. This may be due to the group's current and historical majority among the country's ethnic Chinese population. Some of the nuanced differences between these terms appear to have been lost over the generations, which is why there are reports of the terms being used interchangeably. Finally, Teochew people call themselves $t i{ }^{11} t 6 i u^{33} n a \eta^{55}$ 潮州人 'Teochew people' or $\mathrm{ka}^{33} \mathrm{ki}^{11} \mathrm{na \eta}^{55}$ 家已人 'our own people'. In Cambodia, they may also say they are $k a \eta^{24} p o u^{33} t 6 e^{11} t \partial \eta^{11} n a \eta^{55}$ 東埔寨唐人 'Cambodian Chinese' or $k a \eta^{24}{ }^{2} u^{33} t 6 e^{11} h u a^{11} d z i \eta^{55}$ 柬埔寨华人 'Cambodian Chinese'.

4 The terms that follow have been adapted from Edwards (2009) according to their usages by consultants interviewed for this project. 
In the English literature on the Chinese in Cambodia, the terms "SinoKhmer" and "Sino-Cambodian" are often used. Sino-Khmer traditionally refers to people of mixed Chinese and Khmer heritage (Dorais 1991: 553; Edwards 2009: 176; Tan 2006:155-56), while Sino-Cambodian refers to a broader group of ethnic Chinese people with Cambodian citizenship (Verver 2012: 49). Speakers consulted for this project were generally unfamiliar with the Sino-terms. One speaker preferred to identify as purely Cambodian and would only say Teochew when specifically asked if they were ethnic Chinese, while other speakers and their families identify as "Cambodian Teochew". Therefore, in this chapter, I follow Verver (2012) in adopting the labels "Cambodian Chinese", "ethnic Chinese", or more specifically "Cambodian Teochew".

\subsection{History of the Chinese in Cambodia}

The Chinese have had a long history in Cambodia, with the earliest records coming from Chinese diplomat Zhou Daguan's 周达观 detailed account in 1296 of the Chinese who had settled in an area that is today's Siem Reap (Zhou 2007). Since then, a variety of Chinese groups have made Cambodia their home, including the Hokkien, whose communities date back to the 1400 s (Chan 2005), the Hainanese, who began migrating in 1675 (ibid.), the Cantonese, for whom mass migration started in 1679 (Willmott 1967), and the Teochew, who had an established community in Kampot in the 1800 s (Chan 2005) and opened a dialect association (会馆 huiguan) in Phnom Penh in 1814 (Chen 2015). Huge waves of Teochew immigration came in the 1930 s to the 196os, mostly from Jieyang 揭阳, Chaoyang 潮阳, and Puning 普宁, and by the 196os, the Teochew people overtook the Cantonese to become the majority Chinese group in Cambodia (Willmott 1967). Some sources provided insight into the group's population numbers over time. According to a Portuguese visitor to Cambodia in 1609, it was reported that 3,000 of the 20,000 inhabitants (15\%) of Phnom Penh were Chinese (Schliesinger 2011:199). By 1897, 22,000 of the 50,00o inhabitants (44\%) of Phnom Penh were Chinese (Siphat 2017: 185). In Cambodia as a whole, there were reportedly 106,764 Chinese in 1874 , representing $11 \%$ of the country's population (Schliesinger 2011: 199). By 1967, the Chinese had grown to 425 ,ooo, making up $7.4 \%$ of the Cambodian population, with $75 \%$ reportedly of Teochew origin (Willmott 1967: 17).

Willmott's (1967) detailed ethnography reported that the Chinese were thriving in Cambodia in the 196os. There were 200 Chinese schools across the country, various associations by regional group (Cantonese, Hakka, Hainanese, Hokkien, and Teochew), $3^{1}$ sports clubs in Phnom Penh alone, five Chinese newspapers in the capital city, dedicated cemeteries, and a Chinese hospital (ibid. 87-89). Unfortunately, shortly after he completed his study, the Chinese 
faced some troubling times in Cambodia. Oppression of the group began with the rule of Lon Nol from 1970-75 and his forced closings of Chinese language schools and newspapers, while the Khmer Rouge regime that lasted from 1975-79 led to the deaths of nearly one-half of the ethnic Chinese in Cambodia (Clayton 2006). Finally, when the Vietnamese took over in the 1980s, the Chinese faced continued suppression in retaliation for China's support of the Khmer Rouge (ibid.). As a result of this decades-long oppression, Cambodia saw a mass emigration of the Chinese population, most of whom would never return. Instead, many families settled in places such as Australia (Stevens 1990), Canada (Dorais 1991), France (Aw 2019; Panh \& Bataille 2012; Tan 2006), and the United States (Ly 200o; Tan 2006; Ung 2000). By 1984, there were reportedly only 61,400 Cambodian Chinese in the country (Siphat 2017: 185). Of those who did stay, many experienced a loss of their Chinese language and culture such that "a generation whose parents were principally Teochew speakers ... grew up speaking Khmer" (Nyíri 2015: 15). Fortunately, some did practice their language in secret and were able to pass their Chinese varieties along to the next generations (Clayton 2006; Edwards 2009).

Recent times have seen a resurgence of the Chinese in Cambodia. They have re-established their strength in business (Siphat 2017; Verver 2012), with the help of new migrants from mainland China, Hong Kong, and Taiwan (Chin 2017). There has been a transformation of Chinese media with the establishment of five newspapers, two magazines, and one radio station (Nyíri 2015). Many of the old huiguans have been resurrected (Chen 2015), and Chinese schools have reopened (Bourgerie 2017). Even still, it is challenging to calculate the number of ethnic Chinese in Cambodia because many remain fearful of admitting their background, though there are recent estimates. The Association of Chinese Nationals in Cambodia estimated the population of "pure Chinese" (i.e. not Sino-Khmer) to be between 300,000 and 340,000 in 1995 (Edwards 2009). The 2008 census put the number of Chinese at $1 \%$ of Cambodia's 15.5 million people $(155,000)$ (Siphat 2017: 185), though that was likely an inaccurately low figure. In 2014, The Foundation of Associations of Chinese estimated the population to number around 1 million (Bourgerie 2017: 166). Chen (2009) and Edwards (2009) reported that $80 \%$ of the Chinese in Cambodia are of Teochew origin.

\subsection{Sociolinguistic Situation of the Teochew in Cambodia and Southeast Asia}

While many of the aforementioned sources provided good historical background on the different Chinese communities in Cambodia and information on the governmental persecution they have faced over the years, limited work 
has been done on the language of the Cambodian Chinese, though some studies have provided insights into their sociolinguistic situation. Verver (2012) and Verver and Koning (2018) studied Chinese business practices in Phnom Penh and discovered that the majority of the entrepreneurs were Teochew families who had been in Cambodia for two to four generations. They and other scholars have found most of these families to be multilingual, maintaining their Sinitic variety like Teochew in addition to learning the national language of Khmer, with many, but not all, also studying Mandarin in schools (Chan 2005; Tea \& Nov 2009; Verver 2012; Verver \& Koning 2018; Willmott 1967). Bourgerie (2017) investigated this multilingualism, focusing on the educational system of the ethnic Chinese in Cambodia by collecting data from surveys on language use and language background in four major Chinese schools in Phnom Penh from 146 respondents in grades 11 and 12. The author found that the younger generation of Chinese are "proud of their heritage and see their identity as a status marker" (Bourgerie 2017: 177). Pride in a Teochew/Chinese heritage and the significance of a Chinese identity, especially for entrepreneurship, was also noted by Verver (2012) and Verver \& Koning (2018). Meanwhile, it was found that language use and choice is situational. While Khmer, Mandarin, and other Sinitic varieties are all used to some extent at home (Bourgerie 2017; Nyíri 2012), Khmer is used with non-Chinese peers (Bourgerie 2017), Teochew (and Cantonese) is spoken with ethnic peers (Bourgerie 2017; Chen 2015) and often in business (Tea \& Nov 2009; Verver \& Koning 2018), and Mandarin is spoken in school and for association matters (Chen 2015: 121), and in business relations with mainland Chinese and in Southeast Asia (Verver \& Koning 2018). Data from the current researcher's observations and interviews with speakers consulted for this project and their family members confirm these findings.

While Teochew is still being spoken to some extent by the younger generation in Cambodia, Khmer, Mandarin, and English are all playing a role in its decline. Similar language shifts are being seen in Indonesia, Malaysia, Singapore, Thailand, and more, for many of the same reasons. First, not speaking a minority language, such as Teochew, at home is detrimental to its transmission (Fishman 1991). It has been reported that many families have moved away from Teochew in the home domain in Cambodia (Nyíri 2012), Indonesia (Veniranda 2015), Malaysia (Ong 2018; Sim 2012; Wang 2016), Singapore (Lee 2015; Li et al. 1997; Ng 1996), and Thailand (Lee 2014). Of the families in Cambodia consulted for this study, it was similarly noted that children raised in households that primarily spoke Khmer were not likely to speak Teochew proficiently. Interestingly, in Thailand, Lee (2014: 191) found that some study participants were able to learn Teochew from business settings, despite speaking Thai at home, though this is very rare. 
Institutional factors such as government policy and the language of education have also played a big role in each of these countries. As mentioned above, political policies during the 1970s and 1980s greatly crippled the Cambodian Teochew community's language use. Furthermore, Chinese schools in Cambodia began switching the language of instruction from regional varieties to Mandarin when the country established diplomatic relations with China in 1958 (Edwards 2009: 185; Goh 2011: 11; Willmott 1967: 88). When the schools reopened in the 1990s, instruction continued in Mandarin, resulting in the "spread of Mandarin among young people at the expense of Teochiu" (Nyíri 2012: 106). In Singapore, the launch of the governmental Speak Mandarin Campaign in 1979 was instrumental in a similar move away from regional varieties (Lee 2015; Li et al. 1997; Ng 1996). Teochew schools persisted with the support of clan associations until that time, at which point "cultural classes" were taught instead, typically in Mandarin (Li et al. 1997). Today, English is the language of instruction for all schools in Singapore, while Mandarin is offered as a subject. Neighbouring Malaysia had their own Speak Mandarin Campaign launched by the Selangor Chinese Chamber of Commerce in 1980, to great effect (Ong 2018; Sim 2012). Mandarin had already replaced local varieties in Chinese schools in the region, starting in the 1920 (Wang 2016). ${ }^{5}$ Despite setbacks over the years - such as restrictions on government funding - at present there are over 1,00o Mandarin-medium schools across Malaysia (Ong 2018). National policy has also played a role in Indonesia where the use of Teochew took a big hit in the 196os with the country's ban on Chinese culture and language (Stenberg 2015; Veniranda 2015), though the extent of the ban and its effects vary. While Veniranda wrote of personally experiencing discouragement from teachers of the use of Teochew and other mother tongues during her schooling in Pontianak in the 1970s and 1980s, two of her speaker consultants did not experience such a prohibition (Veniranda 2015: 20). Stenberg (2015) found that the relative remoteness and the density of Teochew communities in Pontianak helped stave off some of the effects of the ban, as compared to the Chinese in Java. Abolishment of the prohibition in 1999 led to a revitalization of Chinese culture and the use of Teochew, as well as the addition of Mandarin as an extracurricular activity or obligatory subject in schools (Veniranda 2015). In Thailand, schools began shifting to Mandarin instruction around 1930 (Chokkajitsumpun 1998). However, from 1939 to 1989, various governmental policies, nationalistic ideology, and pressures for the Chinese to excel in the Thai language and assimilate have restricted Mandarin education in different ways and reduced Teochew intergenerational transmission

5 Also see Hoogervorst (this volume) on the early history of Mandarin in Indonesia. 
(Chokkajitsumpun 1998; Morita 2007). Since 1989, Mandarin has seen a revival due to changes in Thai national policy in support of the study of the language (Chokkajitsumpun 1998) and recent studies point to Mandarin being the most widely spoken Chinese language in Thailand today (Lee 2014; Rappa 2014).

Language practices are also shifting in business. Though Teochew is still dominant in the business community in Thailand (Lee 2014; Rappa 2014), and speaking the language is valuable in niche markets such as the rice trade across Thailand, Laos, Vietnam, and Cambodia, Mandarin has become the de facto lingua franca in entrepreneurship throughout Southeast Asia, along with English (Verver \& Koning 2018). As such, Mandarin and English are seen as valuable languages to learn for business opportunities, resulting in an increase of speakers, often at the expense of Teochew as it is seen as a language of low prestige with little economic or instrumental value (Chokkajitsumpun 1998; Lee 2015; Li et al. 1997; Ng 1996; Quek 2013). For example, in the markets of Johor Baru, Malaysia, that used to be dominated by the Teochew language, Wang (2012) instead found Mandarin used in 90.9\% of the business interactions.

In addition to economic reasons, a common trend found in the increasing use of Mandarin was the belief that speaking it would unite the various Chinese groups in the respective countries (Bourgerie 2017; Chokkajitsumpun 1998; Kyne 1999; Lee 2015; Li et al. 1997; Ong 2018; Sim 2012; Stenberg 2015). Finally, exogamy also lead to language shift for Teochews in Cambodia (Filippi 2010; Willmott 2006), Indonesia (Stenberg 2015; Veniranda 2015), Malaysia (Ong 2018; Sim 2012), Singapore (Ng 1996; Quek 2013), and Thailand (Lee 2014).

In summation, several factors are working against the continued transmission of Teochew throughout Southeast Asia. And it can be hard to reverse these trends. As Quek (2013) found, language shift in Singapore has led to a whole generation lacking the Teochew proficiency to pass the knowledge on to their children, even though they reported wanting to. Two of the families I worked with in Cambodia described similar situations and it is likely that this is also the case for many Teochews in Indonesia, Malaysia, and Thailand. Thus it is especially important to carry out language documentation work in these communities in order to create a lasting record of the languages. Additionally, working with communities and recording their speech is a way to further emphasize to them and others that their language is important and worthy of study, and to encourage intergenerational transmission.

\subsection{Sinitic Influence on Khmer and Thai}

Despite the more recent language shift, it has been shown that Cambodian Chinese have been (at least) bilingual for multiple generations. Thus, hundreds of years of contact between Khmer and Chinese has created an 
environment conducive to language change. Though the focus of this chapter is on Khmer's influence on Cambodian Teochew, Chinese varieties have also been found to have affected Khmer vocabulary. This is a significant feature of the Sinophone, in which the local culture is in dialogue with other languages of that location (Shih 2013: 8). The impact of Teochew and other varieties is unsurprising given Cambodia's high percentage of Chinese historically, especially in regions such as the capital city of Phnom Penh. The group was and is "an aggressive social and economic minority" (Pou \& Jenner 1973: 1), with significant importance and influence, especially in the business sector.

Pou and Jenner (1973) investigated Chinese lexical influence and found 300 words in Khmer that were borrowed from various Sinitic varieties including Cantonese, Hokkien, and Teochew. The authors attempted to attribute the source of each word to one of the Sinitic varieties. For example $c^{h} a$ ' 火小 'fry' ${ }^{6}$ that became Khmer chaa §o was attributed to Amoy Hokkien (ibid. 47), while $p^{h} \breve{u} e$ 被 'blanket' that became Khmer phииәј ్ㅀㅀ was said to come from Teochew (ibid. 16). In several cases, the Chinese source was the same in multiple varieties, so the exact donor language could not be determined, such as with só 锁 'lock'. This became Khmer saao โถ่, and was attributed to Amoy/Hokkien/ Cantonese (ibid. 83). Pou and Jenner noted that the bulk of items appeared closest to Hokkien (1973: 4). This could be because the Hokkiens were reportedly the first Chinese group to settle in Cambodia (Chan 2005; Siphat 2017). The vocabulary items were typically new things introduced by the Chinese in Cambodia including terms from commerce and navigation $(22 \%)$, food and articles of use $(21 \%$ each), diversions such as gambling and theatre $(6 \%)$, kinship terms (5\%), technological terms (arts and crafts) (4\%), administrative and legal $(2 \%)$, religious terms $(2 \%)$, miscellaneous verbs $(8 \%)$, and miscellaneous nouns (7.5\%). Huang and Mo (2017) also looked at Chinese loanwords in Khmer, claiming to have identified more than 250 borrowed Chinese words in Khmer, most which reportedly came from Teochew. As such, the authors compared the Teochew pronunciation to the Khmer loanword pronunciation and reported on any sound changes. Only 50 words were provided, many overlapping with Pou and Jenner (1973). It is unclear how many of Pou and Jenner's loanwords are still used in Khmer today and to what extent as several of the words they listed were not recognized by the Vacanānukram Khmēr

6 Words from Pou and Jenner (1973) are unchanged in form. The authors adopted a uniform system of transliteration for their Chinese data from various sources. Since they were unconcerned with tone, Chinese words appeared with the same diacritics as in their original source transcriptions. 
dictionary and some were noted to be used only amongst Chinese speakers. According to Edwards (2012: 9), Chinese familial terms such as jie 姐 'big sister' and $y i$ 姨 'auntie' are being used nowadays, even between Khmers.

Chinese has similarly had a great influence on other languages in Southeast Asia. Several works have looked at the language family's effect on the Thai language. Egerod (1958) presented 181 words from the Swatow 汕头 variety of Teochew that have been adopted into Thai, explaining how the words' pronunciations changed in the borrowed Thai forms. Similar to Pou and Jenner (1973), Egerod found that the Chinese loanwords were often related to commerce, kinship, food and beverage, and leisure events. Gong (2000) likewise looked at 315 Swatow loanwords in Thai, while Gyarunsut (1983) compiled a list of over 46o Chinese terms used in modern Thai. Cooper (2020) created an online dictionary of more than 75 o Chinese roots, loans, and cognates in Thai using data compiled from Gyarunsut (1983), Gong (2000), and Manomaivibool (1975). Of these, nearly 350 are attributed to Teochew. Finally, Lin (2006), found $100+$ Teochew loanwords in Thai in areas such as people designations, business activities, foodstuffs, and daily necessities.

Table 3.1 below compares person terminology borrowed from Teochew/ Chinese found in Thai, Khmer, and Lao. As mentioned above, exact language origins are difficult to pinpoint. The majority of the words in Table 3.1 were attributed to Teochew but a few were said to come from another Chinese variety.

TABLE 3.1 Teochew loanwords in Khmer, Thai, and Lao

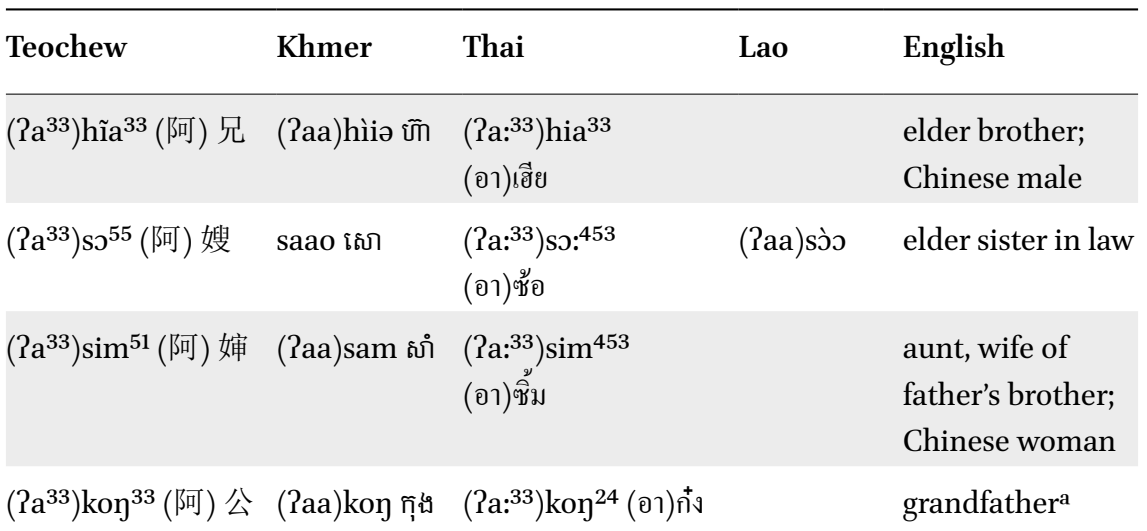

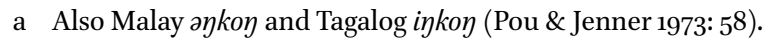


TABLE 3.1 Teochew loanwords in Khmer, Thai, and Lao (cont.)

\begin{tabular}{|c|c|c|c|c|}
\hline Teochew & Khmer & Thai & Lao & English \\
\hline$\left(\mathrm{Pa}^{33}\right)$ kow $^{33}$ (阿) 姑 & kòow กู่ & $\begin{array}{l}\left(\text { (a: }{ }^{33}\right) \mathrm{ko:}^{33} \\
\text { (อา)โก }\end{array}$ & (?aa)kōo & $\begin{array}{l}\text { aunt, father's } \\
\text { sisterb }^{\text {b }}\end{array}$ \\
\hline$\left(2 \mathrm{a}^{33}\right) \mathrm{ku}^{24}$ (阿) 舅 & (Paa)kuu ${ }^{c}$ & $\begin{array}{l}\left(2 \mathrm{a}:^{33}\right) \mathrm{ku}:^{24} \\
\text { (อา)กู่ }\end{array}$ & & $\begin{array}{l}\text { uncle, mother's } \\
\text { brother }\end{array}$ \\
\hline$\left(\mathrm{Pa}^{33}\right) \mathrm{mue}^{21}$ (阿) 妹 & $\begin{array}{l}\text { (?aa)múuej } \\
\text { ตู้๘ }\end{array}$ & $\begin{array}{l}\left(\mathrm{Pa}^{33}\right) \mathrm{muaj}^{24} \\
\text { (อา)หมวย }\end{array}$ & (?aa)mûej & $\begin{array}{l}\text { younger sister; } \\
\text { Chinese girl }\end{array}$ \\
\hline$\left(\mathrm{a}^{33}\right) \mathrm{p}^{2} \mathrm{P}^{22}$ (阿) 伯 & (?aa)pè? ธุิ & $\begin{array}{l}\left(2 \mathrm{a}:{ }^{33}\right) \mathrm{p}^{255}{ }^{55} \\
\text { (อา)แป๊ะ }\end{array}$ & Paаp $\bar{\varepsilon} ?$ & $\begin{array}{l}\text { uncle, father's } \\
\text { brother; old man }\end{array}$ \\
\hline$\left(\mathrm{Pa}^{33}\right) \mathrm{ti}^{24}$ (阿) 弟 & (Paa)tii ${ }^{\mathrm{d}}$ & $\left(\mathrm{Pa}:{ }^{33}\right) \mathrm{ti}^{24}$ (อา)ตี๋ & & younger brother \\
\hline$\left(2 a^{33}\right) t s \varepsilon^{51}$ (阿) 姐 & саaع โัษ & $\left(2 \mathrm{a}:{ }^{33}\right)$ tce: $^{453}($ อา)เจ๊ & cee & older sister \\
\hline$\left(\mathrm{Pa}^{33}\right) \mathrm{Pi}^{55}$ (阿) 姨 & & $\left(\mathrm{Pa}:{ }^{33}\right) \mathrm{Pi}^{4453}$ (อา)อี๊ & & $\begin{array}{l}\text { aunt, mother's } \\
\text { sister }\end{array}$ \\
\hline haj $^{24}$ nam $^{55}$ 海南 & $\begin{array}{l}\text { hajnam } \\
\text { ถักภณกs }\end{array}$ & $\begin{array}{l}\text { haj24lam²4 } \\
\text { ไหหลำ }\end{array}$ & & $\begin{array}{l}\text { Hainan, } \\
\text { Hainanese }\end{array}$ \\
\hline hĩo ${ }^{33}$ koy $^{33}$ 香公 & & $\begin{array}{l}\text { hia }^{33} \text { koj }^{33} \\
\text { เฮียกง }\end{array}$ & & $\begin{array}{l}\text { the keeper of a } \\
\text { temple }\end{array}$ \\
\hline huaj33 番 & & huan $^{33}$ ฮวน & & $\begin{array}{l}\text { foreigner; } \\
\text { non-Chinese }\end{array}$ \\
\hline $\mathrm{ku \eta}^{33} \mathrm{si}^{33}$ 军师 & & kun $^{33}$ si: $^{33}$ กุนซือ & & an advisor \\
\hline now $^{33}$ kĩa $^{51}$ 孥仔 & & noך $^{33} \mathrm{kia}^{55}$ โนงเกี๊ยะ & & child \\
\hline sã ${ }^{33}$ pũa $^{55}$ 三盘 & & $\mathrm{sa}:{ }^{33}$ pua $^{453}$ ซาปั๊ว & & $\begin{array}{l}\text { a third-level } \\
\text { seller }\end{array}$ \\
\hline $\begin{array}{l}\mathrm{sam}^{33} \mathrm{po}^{24} \mathrm{ko \eta}^{33} \\
\text { 三保公 }\end{array}$ & & $\begin{array}{l}\text { sam }^{33} \text { po: }{ }^{33} \mathrm{koy}^{33} \\
\text { ซำปอกง }\end{array}$ & & $\begin{array}{l}\text { a Chinese } \\
\text { Buddha image }\end{array}$ \\
\hline
\end{tabular}

b See also Malay ankoh (Hoogervorst, this volume Table 7.7).

c This word is primarily used among Cambodian Chinese families. It is given in Huang \& Mo (2017: 96) but is absent in Pou \& Jenner (1973).

d Primarily used among Cambodian Chinese families. 
TABLE 3.1 Teochew loanwords in Khmer, Thai, and Lao (cont.)

\begin{tabular}{|c|c|c|c|c|}
\hline Teochew & Khmer & Thai & Lao & English \\
\hline si $^{33}$ hĩa $^{33}$ 师兄 & & si: ${ }^{33}$ hia $^{33}$ ซือเฮีย & & $\begin{array}{l}\text { form of address } \\
\text { for older male } \\
\text { classmate }\end{array}$ \\
\hline$s \dot{s}^{33} \mathrm{ts}^{51}$ 师父 & & si: ${ }^{33}$ tce: $:^{453}$ ซือแป๋ & & $\begin{array}{l}\text { form of address } \\
\text { for teacher }\end{array}$ \\
\hline $\operatorname{sia}^{11}$ 舍 & & $\operatorname{sia}^{22}$ เสี่ย & & $\begin{array}{l}\text { a wealthy } \\
\text { Chinese }\end{array}$ \\
\hline $\operatorname{si\eta }{ }^{33} \tilde{\varepsilon}^{33}$ 先生 & $\begin{array}{l}\text { sinsaae } \\
\text { ถุิธุ็ธธ์ }\end{array}$ & $\sin ^{33} s \varepsilon:^{24}$ นแส & & doctor; teacher \\
\hline taj ${ }^{21} \mathrm{ko \eta}^{33}$ 舵公 & tajkoy รืกกุ่นิ & taj $^{41} \mathrm{ko \eta}^{24}$ ไต้ก๋ง & & helmsman \\
\hline $\mathrm{t}^{\mathrm{h}} \mathrm{aw}^{21} \mathrm{k} \varepsilon^{33}$ 头家 & $\begin{array}{l}\text { thawkaae } \\
\text { โษ่โก๊ }\end{array}$ & thaw ${ }^{41} \mathrm{k} \varepsilon:^{22}$ เถ้าแก่ & thâwkē $\bar{\varepsilon}$ & $\begin{array}{l}\text { shopkeeper; } \\
\text { tradesman; boss }\end{array}$ \\
\hline $\begin{array}{l}\mathrm{t}^{\mathrm{h}} \mathrm{aw}^{21} \mathrm{k}^{33} \mathrm{ni}^{55} \\
\text { 头家娘 }\end{array}$ & & $\begin{array}{l}\text { thaw }^{41} \mathrm{ke}{ }^{33} \mathrm{nia}^{453} \\
\text { เถ้าเกเนี้ย }\end{array}$ & & wife of the boss \\
\hline $\begin{array}{l}\mathrm{t}^{\mathrm{h}} \mathrm{aw}^{21} \mathrm{na \eta}^{55} \\
\text { 头人 }\end{array}$ & & thaw $^{41}$ naj $^{453}$ เถ้านั้ง & & $\begin{array}{l}\text { a respected, elder } \\
\text { Chinese }\end{array}$ \\
\hline $\mathrm{tia}^{35}$ 爹 & tìiə โథ̧ & $\mathrm{tia}^{22}$ เตี่ย & tīə & father \\
\hline $\mathrm{tio}^{21} \mathrm{tsiw}^{33}$ 潮州 & tìiəciiw §านีร & $\mathrm{t} \varepsilon:^{41} \mathrm{tciw}^{24}$ แต้จั๋ว & tēechǐw & Teochew \\
\hline $\operatorname{tin}^{21} n^{5}{ }^{55}$ 唐人 & & $\operatorname{tin}^{41} \mathrm{na \eta}^{453}$ ตึ้งนั้ง & & Chinese person \\
\hline $\mathrm{ts}^{32} \mathrm{sũa}^{33}$ 座山 & & tcaw $^{41}$ sua $^{24}$ เจ้าสัว & & $\begin{array}{l}\text { a rich man, esp. } \\
\text { Chinese }\end{array}$ \\
\hline $\mathrm{tsek}^{22}$ 叔 & (?aa)cว̀k ธิก & $\operatorname{tcek}^{55}$ เจ๊ก & cēk & a Chinese man \\
\hline$t \sin ^{33} \mathrm{te \eta}^{33}$ 亲丁 & & tci:n ${ }^{33}$ tej $^{33}$ จีนเต็ง & & a trusted follower \\
\hline $\mathrm{tsu}^{21} \mathrm{tsu}^{51}$ 船主 & cə̀ncuu ติ sત్ర & t6un ${ }^{41}$ tcu: 453 จุ้นจู๊ & & $\begin{array}{l}\text { the master of a } \\
\text { ship }\end{array}$ \\
\hline$t{ }^{21} p u j{ }^{55}$ 肥大 & & tua $^{41}{ }^{1}$ puj $^{453}$ ตั้วปุ๊ย & & $\begin{array}{l}\text { to be pot-bellied, } \\
\text { fat }\end{array}$ \\
\hline${ }_{\mathrm{zi}}{ }^{21} \mathrm{pũa}^{55}$ 二盘 & & $\mathrm{ji}:{ }^{41}$ pua $^{453}$ ยี่ป๊๊ว & & $\begin{array}{l}\text { a second-level } \\
\text { seller }\end{array}$ \\
\hline
\end{tabular}


The Teochew pronunciations and Chinese characters in Table 3.1 above come from Gyarunsut (1983). English translations have been adapted from Cooper (2020) and Pou \& Jenner (1973). The Khmer and Lao pronunciations are from Pou \& Jenner (1973) unless otherwise noted, but their $\langle\mathrm{q}\rangle$ has been replaced by $\langle 1\rangle$. Thai script and pronunciations come from Gyarunsut (1983). Note that exact usages of these terms may vary between Teochew, Khmer, Thai, and the other languages, as is common with loanwords. English definitions have been combined for simplicity. See Cooper (2020) and Pou \& Jenner (1973) for more nuanced usages.

Khmer Loanwords in Cambodian Teochew

The Chinese, with their long history in Cambodia, have influenced the Khmer vocabulary, yet the reverse is also true. This section explores Khmer loanwords in Cambodian Teochew, the language of the majority ethnic Chinese group in Cambodia.

\subsection{Methodology}

Data was gathered from nine speakers in Phnom Penh over four trips made in 2018-2020. Additionally, this chapter integrates data from two speakers consulted in McFarland (2017) who immigrated to the United States in the 198os. Seven consultants were found through the researcher's familial connections in Cambodia and four were recruited via direct message requests targeted at Phnom Penh residents who were participants of Teochew-related Facebook pages. Informal interviews were conducted with each speaker, and any present family members, where they were asked about their educational and language backgrounds and speaking practices and ideologies. Three generations were identified based on the collected background information and historical events in Cambodia. Generation 1 ( $\mathrm{Gl}$ ) consists of speakers over 65 who were born in Cambodia and grew up before the wartime and Vietnamese occupation (1970-89). Their parents were likely also born in Cambodia or moved there at a very young age. Five speakers were consulted in this category, four females and one male. Generation 2 (G2) is made up of those speakers' children, aged $35^{-65}$. These people were children during the wartime. Three speakers, one female and two males, were consulted in this category. Finally, Generation 3 $\left(G_{3}\right)$ represents the children of G2 who are under 35 . These individuals often attended the Chinese schools that reopened in the 199os. Three female speakers were consulted in this category. All consultants speak Teochew and Khmer, while five also speak English $\left(2 \mathrm{G}_{2},{ }_{3} \mathrm{G}_{3}\right)$, and seven $\left(2 \mathrm{G}_{1},{ }_{2} \mathrm{G}_{2},{ }_{3} \mathrm{G}_{3}\right)$ speak some amount of Mandarin. Interviews were conducted in English with 
G3 speakers and the two G2 speakers from McFarland (2017), and in a mixture of Khmer and Teochew with the G1 speakers and the other G2 speaker via the assistance of English-speaking family members.

A Zoom Q8 Handy video recorder and lapel and headset microphones were used with a $48 \mathrm{kHz}$ sampling rate and 24-bit depth. Consultants were shown pictures of items and actions and asked to produce an appropriate word in Teochew. Prompts consisted of images of local foods and dishes, items from Swadesh's (1955) list of non-cultural vocabulary, and selected words that were listed as loanwords in Singapore Teochew by Goh (2017) and Low (2014). Naturalistic texts were also recorded by having consultants tell stories, describe scenes from picture books, and perform the family problem picture task from San Roque et al. (2012). Some additional data was collected from five of the speakers over Facebook Messenger. The assembled data constituted a preliminary vocabulary of Cambodian Teochew which was then compared to sources on other Teochew varieties including Indonesian (IT) (Peng 2012), Jieyang (JT) (Xu 2007), Singapore (st) (Goh 2017; Li 1991; Low 2014; Yeo 2011), and Thai (тT) (Atchariyasucha 1982). References were also made to historical works on Teochew (HT) from foreign missionaries to China such as Ashmore (1884), Dean (1841), Duffus (1883), Fielde (1878), Fielde (1883), Giles (1877), Goddard (1888), and Lim (1886), as well as to a mobile Teochew dictionary application WhatTCSay (TCKnow LLC. 2015) and an online pronunciation dictionary Mogher.com. If a Cambodian Teochew word was found to be similar to the word form in another Teochew source, it was determined that it was likely not borrowed from Khmer. If a vocabulary item did not resemble the form from any of the other Teochew varieties, or if the word was not present at all in any of the other sources, its Khmer equivalent was found to determine if they were similar. Khmer words were found using online dictionaries and translation services. Comparable words were marked as likely loanwords. Given that Khmer has borrowed extensively from Chinese as shown in the previous section, a final check was made to Pou and Jenner (1973) to confirm the direction of the borrowing. For example, the Cambodian Teochew word $t_{6}^{h} a^{24} t 6^{h} a u^{52}$ 吵吵 'to bother, pester, quarrel' resembles the Khmer word chaachaw with the same meaning. But according to Pou and Jenner, Khmer has borrowed this word from Chinese (1973: 47). Therefore, if a word was found in Pou and Jenner, it was decided that it was not a case of Cambodian Teochew borrowing from Khmer.

\subsection{Loanwords}

After going through the aforementioned process with the collected vocabulary items, it was determined that the items listed in Table 3.2 constitute words 
TABLE 3.2 Khmer loanwords in Cambodian Teochew

\begin{tabular}{|c|c|c|c|}
\hline $\begin{array}{l}\text { Cambodian } \\
\text { Teochew }\end{array}$ & English gloss & $\begin{array}{l}\text { Khmer } \\
\text { etymon }^{\mathrm{a}}\end{array}$ & Other Teochew sources \\
\hline $\mathrm{a}^{11} \mathrm{mok} \mathrm{k}^{5}$ & $\begin{array}{l}\text { amok (curry in } \\
\text { banana leaf) }\end{array}$ & a:mək ราย்ุธุก & \\
\hline bok ${ }^{2} \mathrm{l}^{11} \mathrm{~h} \supset \eta^{55}$ & papaya salad & boklhoy ษุกกููนิ & \\
\hline $\mathrm{buw}^{33}$ & avocado & $\mathrm{p}^{\mathrm{h}} \mathrm{la} 6 \partial^{\circ}$ เั็ููปึี่ & $\begin{array}{l}\text { pak }^{33}{ }^{1 a 1^{55}} \text { 鳄梨, } \mathrm{gu}^{11} \mathrm{ni}^{11} \mathrm{ku}^{53} \\
\text { 牛奶果 (TCKnow 2015) }\end{array}$ \\
\hline bə门 ${ }^{33} \mathrm{tg}^{\mathrm{h}} \mathrm{au}^{52}$ & $\begin{array}{l}\text { Cambodian } \\
\text { crepe, pancake }\end{array}$ & 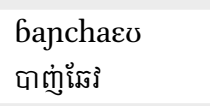 & \\
\hline həu' ${ }^{11} \mathrm{ka}^{11} \mathrm{~d} \supset \mathrm{u}^{11}$ & give gift & kadoø กฺนู & 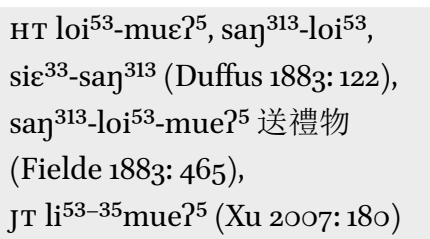 \\
\hline $\mathrm{ka}^{11} \mathrm{lem}^{33}$ & ice cream & $\begin{array}{l}\text { ka:reem } \\
\text { การึ้ษ }\end{array}$ & 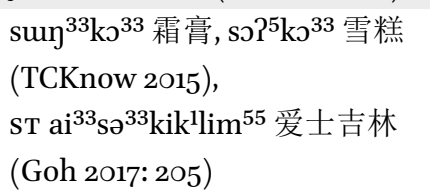 \\
\hline $\mathrm{ka}^{33} \mathrm{la \eta}{ }^{33}$ & $\begin{array}{l}\text { kralan (bamboo } \\
\text { sticky rice) }\end{array}$ & krola:n [กழ్చిన & \\
\hline 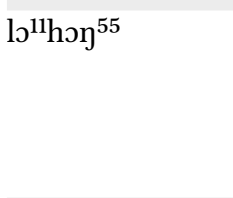 & papaya & lhoy ถู่นุน & $\begin{array}{l}\text { Hт bak } \text { kue }^{33} \text { 木瓜 (Fielde 1883: } \\
\text { 277), IT pakue, nikue (Peng } \\
\text { 2012: 33), sт bak }{ }^{5} \text { kue }^{33} \text { 木瓜, } \\
\text { ni }^{33} \text { kue }^{33} \text { 奶瓜 (Goh 2017: 134) }\end{array}$ \\
\hline $\begin{array}{l}\mathrm{l} \mathrm{k}^{2} \mathrm{la}^{5}, \\
\mathrm{t}_{6} \mathrm{~h}^{\mathrm{h}} \mathrm{a}^{52-24} \mathrm{lok}^{2} \mathrm{la} \mathrm{P}^{5}\end{array}$ & $\begin{array}{l}\text { lok lak (stir-fried } \\
\text { beef cubes) }\end{array}$ & 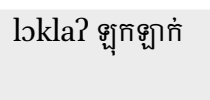 & \\
\hline $\operatorname{ma\eta }^{11} \mathrm{k}^{\mathrm{h}} \mathrm{u} \mathrm{P}^{2}$ & $\begin{array}{l}\text { mangosteen } \\
\text { (Garcinia } \\
\text { mangostana) }\end{array}$ & 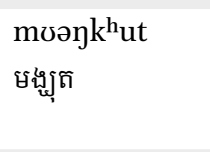 & $\begin{array}{l}\text { ST maך }{ }^{55} \text { hek }^{1} \text { 芒黑 (Goh 2017: } \\
\text { 209) }\end{array}$ \\
\hline $\mathrm{po}^{33} \mathrm{la}^{33} \mathrm{~h} \supset \mathrm{k}^{5}$ & $\begin{array}{l}\text { prahok } \\
\text { (fermented } \\
\text { fish paste) }\end{array}$ & prohok [ษธุุก & \\
\hline
\end{tabular}

a Filippi and Hiep (2016) and Sak-Humphry (2015) were referenced for Khmer pronunciation. 
TABLE 3.2 Khmer loanwords in Cambodian Teochew (cont.)

\begin{tabular}{|c|c|c|c|}
\hline $\begin{array}{l}\text { Cambodian } \\
\text { Teochew }\end{array}$ & English gloss & $\begin{array}{l}\text { Khmer } \\
\text { etymon }\end{array}$ & Other Teochew sources \\
\hline $\mathrm{po}^{33} \mathrm{l}^{52}$ & jungle, forest & prei ถุำ & 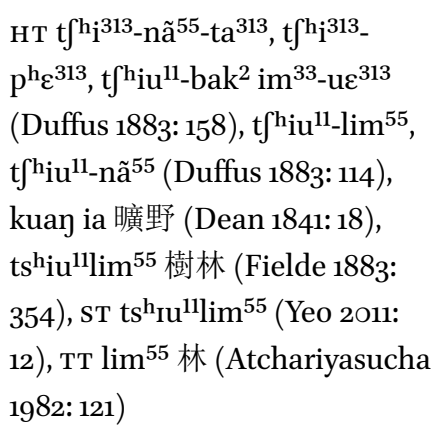 \\
\hline $\mathrm{pi}^{33}$ & $\begin{array}{l}\text { from (time or } \\
\text { place) }\end{array}$ & pi: ตี & 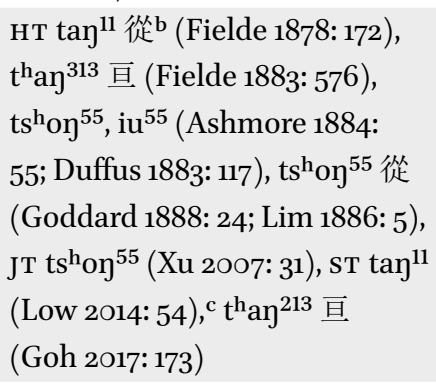 \\
\hline pinj $^{33}$ poๆ $^{33}$ & balloon & 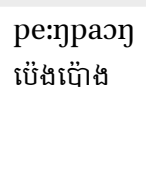 & $\begin{array}{l}\text { HT } \mathrm{p}^{\mathrm{h}} \mathrm{u}^{55}-\mathrm{hun}^{55}-\mathrm{kiu}^{55}, \mathrm{t}^{\mathrm{h}} \mathrm{i \varepsilon n}^{33}{ }_{-} \\
\text {tsun }^{55}, \mathrm{pu}^{33}-\mathrm{t} \mathrm{f}^{\mathrm{h}} \mathrm{ia}^{33}, \mathrm{k}^{\mathrm{h}} \mathrm{i}^{313}-\mathrm{kiu}^{55} \\
\text { (Duffus 1883: 17), sT be }{ }^{33} \mathrm{lo \eta}^{55} \\
\text { 码隆 (Goh 2017: 206) }\end{array}$ \\
\hline $\mathrm{sau}^{33} \mathrm{mau}^{33}$ & $\begin{array}{l}\text { rambutan } \\
\text { (Nephelium } \\
\text { lappaceum) }\end{array}$ & $\begin{array}{l}\text { sa:vma:v } \\
\text { ธารีย̈ติร }\end{array}$ & 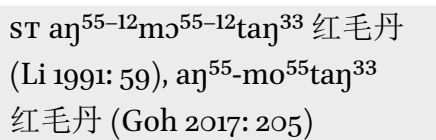 \\
\hline
\end{tabular}

b Fielde (1878: 8) noted that this character is not of direct equivalence but is "of similar signification".

c Low (2014) did not include citation tones in her pitch superscripts. Since the one appearance of $\operatorname{ta}^{11}$ 'from' in her paper was in a sandhi environment, according to her tone sandhi rules, the citation form could be either $\operatorname{ta\eta }^{55}, \operatorname{ta\eta }^{35}$, or $\operatorname{ta\eta }^{11}$. 
that Cambodian Teochew has borrowed from Khmer. The table shows the loanwords in Cambodian Teochew, their English meaning, the Khmer pronunciation, and the equivalents in other Teochew varieties if found in the literature. Chinese characters are provided next to the IPA if they were present in the original source.

\subsection{Integration of Loanwords}

Loanwords are adapted phonologically and morphologically to conform to the constraints of the borrowing language (Kang 2011). In terms of phonological adaptation, the words borrowed from Khmer adhere to the phonotactics of Cambodian Teochew. For example, while Khmer has both /l/ and /r/ in its phonological inventory (Huffman 1967), Cambodian Teochew has only /1/ (Chen 2009; McFarland 2017; Pan 200o). Therefore, Khmer /r/ is pronounced as /l/, as seen in the words for 'jungle', 'prahok', and 'ice cream'. Additionally, while Khmer allows consonant clusters at syllable onset as seen in prei 'jungle', prohok 'prahok', lhoy 'papaya', and krpla:n 'kralan', these are not allowed in Teochew. To resolve this, the loanword could delete one of the two consonants or insert an epenthetic vowel (Miao 2005:105). In the first three instances, we see epenthetic vowel insertion between the two consonants to get $p v^{33} l{ }^{52}, p v^{33} l a^{33} h \mathrm{~h} \mathrm{k}^{5}$, and $\mathrm{lo}^{11} \mathrm{ho \eta}^{55}$. For 'kralan', the $/ \mathrm{r} /$ is deleted to get $\mathrm{ka}^{33} \mathrm{la \eta}^{33}$. Cambodian Teochew also restricts consonants in syllable coda and $/ \mathrm{n} /$ is not allowed. We can see that the final letter of Khmer krola:n 'kralan' is pronounced $/ \mathrm{y} /$ in the Teochew word $\mathrm{ka}^{33} \mathrm{la \eta}{ }^{33}$. Finally, while Khmer is non-tonal, Cambodian Teochew is a tonal language, so each borrowed word gets assigned a tone, as reflected by the pitch values given in the numerical superscripts. ${ }^{7}$ Teochew also has extensive tone sandhi, a phenomenon common in Sinitic languages, where a word in a phrase or sentence will surface with a different tone than when the word appears in isolation. The general rule is that the right-most syllable in a word or utterance retains its citation tone while the other syllables are subject to tone sandhi. ${ }^{8}$ For example, $h u e^{52}$ 'fire' becomes $h u e^{52-24}$ suã $\tilde{a}^{33}$ 'volcano'. Per convention, a word's dictionary/citation tone appears first in the superscript, followed by a hyphen, and then the word's surface tone after undergoing tone sandhi. There is evidence that the Khmer loanwords in Cambodian Teochew undergo tone sandhi as the phrases in (1) show. Similarly, they provide an environment

7 Variation may exist amongst speakers in the word's tone. Even still, borrowed words appear to have been given tones and follow rules of tone sandhi as outlined below.

8 Not all words surface in different tones. Words with mid-level (pitch value: 33 ) and low-level (pitch value: 11) tones remain unchanged in sandhi domains. See McFarland (forthcoming) for a full overview of the tone and tone sandhi patterns in Cambodian Teochew. 
for tone sandhi such that the preceding words surface in their sandhi tones, as shown in (2).

1)
a. $10^{11} h^{15} \eta^{55-11} \quad$ t6ui $^{52}$
ถุ่นใ 水
papaya water
'papaya juice'
b. $\mathrm{a}^{11} \mathrm{mok}^{5-2} \quad h \mathrm{u}^{55}$

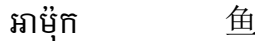
amok fish
'amok fish'

2) a. $\mathrm{t}^{\mathrm{h}} \mathrm{a}^{52-24} \quad \mathrm{lbk}^{2} \mathrm{la}^{5}$

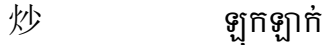

stir-fry lok lak

'stir-fried beef cubes'

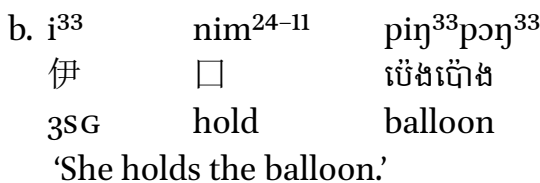

In terms of morphological adaptation, Cambodian Teochew is like other Sinitic languages in having limited morphology, so integration is relatively straightforward. Borrowed words do not need to be inflected for plurality or gender. In Teochew (and also in Khmer), nouns are counted and referred to with a classifier. The word order is number, classifier, noun. The classifier used is dependent on the type of noun. For example, t6ia ${ }^{2}$ 隻 is used with animals and bue $e^{52}$ 尾 with fish. My consultants provided evidence that Khmer loanwords in Cambodian Teochew can be used with a specific classifier like liap 5 粒, used for round things, as in (3), or with the generic classifier kai ${ }^{55}$ 个, which can also be used with most things, as shown in (4).
3) a. $\tilde{a}^{33}$
$\operatorname{liap}^{5-2}$
lo ${ }^{11} h \ni \eta^{55}$
三 粒 约々
three CLF papaya
'three papayas' 
b. sã 33

三

three

$\operatorname{liap}^{5-2}$

粒

CLF

'three mangosteens'

c. $\mathrm{yJ}^{24-11} \quad \operatorname{liap}^{5-2}$

两

two

粒

CLF

'two rambutans'

4)
a. sã $\tilde{3}^{33}$
$\mathrm{kai}^{55-11}$
三
个
CLF
'three papayas'

b. sã $\tilde{3}^{33}$

$\mathrm{kai}^{55-11}$

个

three

CLF

'three mangosteens'

c. $\mathrm{yj}^{24-11}$

两

two

$\mathrm{kai}^{55-11}$

个

CLF

'two rambutans'

d. $\mathrm{si}^{11-53}$

$\mathrm{kai}^{55-11}$

四

four

$\operatorname{man}^{11} \mathrm{k}^{\mathrm{h}} \mathrm{u} \mathbf{P}^{2}$

ษินููกิ

mangosteen

$\mathrm{sau}^{33} \mathrm{mau}^{33}$

ธิรียื่ร

rambutan

lollhon 55

ถู่นใน

papaya

$\operatorname{ma\eta }^{11} k^{h} u P^{2}$

ษินฺูุ

mangosteen

'four balloons'

$\mathrm{sau}^{33} \mathrm{mau}^{33}$

ถัรืยื่ร

rambutan

$\operatorname{pin}^{33} \mathrm{po \eta}^{33}$

เบิน์เบิใน้

balloon

Khmer also has limited morphology, though one prefix used is $p^{h} / a \varepsilon$ meaning 'fruit'. The word $p^{h} l a \varepsilon b \partial^{\circ}$ 'avocado' can be translated to 'fruit-butter'. In isolation, $6 \partial^{\circ}$ is a French borrowing in Khmer meaning 'butter'. The word $p^{h} l a \varepsilon$

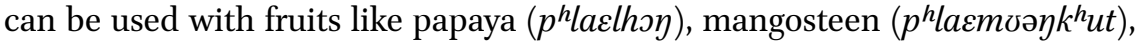
and rambutan ( $p^{h}$ lassarvmarv). For these words, $p^{h} l a \varepsilon$ is not obligatory as the words without said prefix do not have another meaning, unlike with 'avocado' $\left(p^{h}\right.$ lasb $\left.\partial^{\circ}\right)$ and 'butter' ( $\left.6 \partial^{\circ}\right)$. Importantly, when Cambodian Teochew borrows the Khmer word, $p^{h} l a \varepsilon$ is never used. The loanword for avocado becomes solely 
$b u^{33}$. With these mentioned stipulations, loanwords from Khmer integrate seamlessly into the Cambodian Teochew language.

\subsection{Speaker Variation}

It should be noted that not all of the eleven speakers interviewed for this chapter necessarily use all the words in Table 3.2. Table 3.3 shows a breakdown of the number of speakers in the gathered data using each word and the alternate words used, if any. 'No word' signifies that the speaker was shown a prompt for the item and they indicated they did not know the word in Teochew. 'Unknown' signifies that it is not known if the speaker uses the word in their Teochew. This is due to an expanding list of prompts in later speaker consultations and the researcher's inability to re-interview speakers from early consultations. Though this study did not have enough participants to present anything conclusive on gender and generational variations, any points of interest related to speaker age will be covered in section 4. At least three speakers needed to use the loanword for it to be included in Table 3.2. 'Jungle', 'mangosteen', 'rambutan', 'papaya, 'papaya salad', 'prahok', 'pancake/crepe', 'ice cream', 'balloon', and 'from' are also attested by the Cambodian Teochew diaspora in the Facebook group Gaginang.

TABLE 3.3 Breakdown of the count of speakers using each word

\begin{tabular}{|c|c|c|}
\hline English gloss & Word used & Count, generation, gender \\
\hline \multirow[t]{4}{*}{ jungle, forest } & $7 \mathrm{po}^{33} \mathrm{l}^{52}$ & ${ }_{2} \mathrm{G} 1 \mathrm{~F}, \mathrm{G} 1 \mathrm{M}, \mathrm{G} 2 \mathrm{~F}, 2 \mathrm{G} 2 \mathrm{M}, \mathrm{G}_{3} \mathrm{~F}$ \\
\hline & $1 \mathrm{po}^{33} \mathrm{loi}^{52}+\mathrm{t}^{\mathrm{h}} \mathrm{iu}^{11} \mathrm{lim}^{55}$ & $\mathrm{GlF}$ \\
\hline & $1 \mathrm{t}^{\mathrm{h}} \mathrm{iu}^{11} \lim ^{55}$ & $\mathrm{G1F}$ \\
\hline & 2 no word & ${ }_{2} \mathrm{G}_{3} \mathrm{~F}$ \\
\hline \multirow[t]{2}{*}{ mangosteen } & $10 \operatorname{ma\eta }^{11} \mathrm{k}^{\mathrm{h}} \mathrm{u} \mathrm{P}^{2}$ & ${ }_{4} \mathrm{G} 1 \mathrm{~F}, \mathrm{G}_{2} \mathrm{~F},{ }_{2} \mathrm{G}_{2} \mathrm{M},{ }_{3} \mathrm{G}_{3} \mathrm{~F}$ \\
\hline & 1 unknown & $\mathrm{G} 1 \mathrm{M}$ \\
\hline \multirow[t]{2}{*}{ rambutan } & $10 \mathrm{sau}^{33} \mathrm{mau}^{33}$ & ${ }_{4} \mathrm{G} 1 \mathrm{~F}, \mathrm{G} 2 \mathrm{~F},{ }_{2} \mathrm{G}_{2} \mathrm{M},{ }_{3} \mathrm{G}_{3} \mathrm{~F}$ \\
\hline & 1 unknown & $\mathrm{G} 1 \mathrm{M}$ \\
\hline \multirow[t]{6}{*}{ avocado } & $4 \mathrm{buu}^{33}$ & ${ }_{3} \mathrm{GiF}, \mathrm{G}_{3} \mathrm{~F}$ \\
\hline & $1 \mathrm{gu}^{55-11} \mathrm{ni}^{11} \mathrm{kue}^{52}$ & $\mathrm{G}_{3} \mathrm{~F}$ \\
\hline & $1 \mathrm{gu}^{55-11} \mathrm{iu}^{55-11} \mathrm{kue}^{52}$ & G2M \\
\hline & 1 a:vək ${ }^{h} a: d o v$ & $\mathrm{G}_{3} \mathrm{~F}$ \\
\hline & 3 no word & $\mathrm{G} 1 \mathrm{~F}, \mathrm{G} 2 \mathrm{~F}, \mathrm{G} 2 \mathrm{M}$ \\
\hline & 1 unknown & $\mathrm{G} 1 \mathrm{M}$ \\
\hline \multirow[t]{2}{*}{ papaya } & 10 l $3^{11} h ว \eta^{55}$ & ${ }_{4} \mathrm{G} 1 \mathrm{~F}, \mathrm{G}_{2} \mathrm{~F},{ }_{2} \mathrm{G}_{2} \mathrm{M},{ }_{3} \mathrm{G}_{3} \mathrm{~F}$ \\
\hline & 1 unknown & $\mathrm{GiM}$ \\
\hline
\end{tabular}


TABLE 3.3 Breakdown of the count of speakers using each word (cont.)

\begin{tabular}{|c|c|c|}
\hline English gloss & Word used & Count, generation, gender \\
\hline papaya salad & 11 bok $^{2} \mathrm{l}^{11} \mathrm{~h} \mathrm{j}^{55}$ & all \\
\hline prahok & $11 \mathrm{po}^{33} \mathrm{la}^{33} \mathrm{~h} \mathrm{k}^{5}$ & all \\
\hline Cambodian crepe & 11 bəท $^{33} t_{6}{ }^{h} a u^{52}$ & all \\
\hline \multirow[t]{4}{*}{ ice cream } & 7 ka $^{11} \mathrm{lem}^{33}$ & ${ }_{3} \mathrm{G} 1 \mathrm{~F}, \mathrm{G} 2 \mathrm{~F}, \mathrm{G} 2 \mathrm{M},{ }_{2} \mathrm{G}_{3} \mathrm{~F}$ \\
\hline & $1 \operatorname{sio}^{2-5} \mathrm{kj}^{33}$ & $\mathrm{G}_{3} \mathrm{~F}$ \\
\hline & $1 \mathrm{sə \eta}^{33} \mathrm{kj}^{33}$ & $\mathrm{GiF}$ \\
\hline & 2 unknown & G1M, G2M \\
\hline \multirow[t]{4}{*}{ kralan } & $3 \mathrm{ka}^{33} \mathrm{la \eta} 33$ & $\mathrm{G} 1 \mathrm{~F},{ }_{2} \mathrm{G}_{3} \mathrm{~F}$ \\
\hline & 2 tek $^{2-5} \mathrm{k}^{33} \mathrm{kue}^{52}$ & $\mathrm{G1F}, \mathrm{G} 2 \mathrm{M}$ \\
\hline & 2 no word & $\mathrm{G}_{2} \mathrm{~F}, \mathrm{G}_{3} \mathrm{~F}$ \\
\hline & 4 unknown & ${ }_{2} \mathrm{G} 1 \mathrm{~F}, \mathrm{G1M}, \mathrm{G} 2 \mathrm{M}$ \\
\hline \multirow[t]{3}{*}{ lok lak } & 8 lok$^{2} l a 2^{5}$ & ${ }_{2} \mathrm{G} 1 \mathrm{~F}, \mathrm{G} 1 \mathrm{M}, \mathrm{G} 2 \mathrm{~F},{ }_{2} \mathrm{G}_{2} \mathrm{M}, \mathrm{G}_{3} \mathrm{~F}$ \\
\hline & $3 \mathrm{t}^{\mathrm{h}} \mathrm{a}^{52-24} \mathrm{lok}^{2} \mathrm{laP}^{5}$ & ${ }_{2} \mathrm{GiF}, \mathrm{G}_{3} \mathrm{~F}$ \\
\hline & 1 unknown & $\mathrm{G}_{3} \mathrm{~F}$ \\
\hline \multirow[t]{2}{*}{ amok } & $9 \mathrm{a}^{11} \mathrm{mok}^{5}$ & ${ }_{4} \mathrm{G1F}, \mathrm{G}_{2} \mathrm{~F},{ }_{2} \mathrm{G}_{2} \mathrm{M},{ }_{2} \mathrm{G}_{3} \mathrm{~F}$ \\
\hline & 2 unknown & $\mathrm{G} 1 \mathrm{M}, \mathrm{G}_{3} \mathrm{~F}$ \\
\hline \multirow[t]{2}{*}{ to give a gift } & $3 \mathrm{~h}^{11} \mathrm{ka}^{11} \mathrm{~d} \supset \mathrm{u}^{11}$ & ${ }_{3} \mathrm{G}_{3} \mathrm{~F}$ \\
\hline & $2 \operatorname{sa\eta }^{53} \mathrm{l}^{52}$ & $\mathrm{G}_{2} \mathrm{~F}, \mathrm{G}_{2} \mathrm{M}$ \\
\hline to gift something & 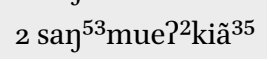 & ${ }_{2} \mathrm{G} 1 \mathrm{~F}$ \\
\hline to gift a book & $1 \mathrm{sa \eta}^{53} \mathrm{pou}^{24}$ & $\mathrm{GiF}$ \\
\hline to give & 3 hวu $^{11}$ & $\mathrm{G1F}, \mathrm{G1M}, \mathrm{G} 2 \mathrm{M}$ \\
\hline \multirow[t]{2}{*}{ from } & $3 \mathrm{pi}^{33}$ & ${ }_{3} \mathrm{G}_{3} \mathrm{~F}$ \\
\hline & 6 unknown & ${ }_{4} \mathrm{G1F}, \mathrm{G1M}, \mathrm{G}_{2} \mathrm{~F},{ }_{2} \mathrm{G}_{2} \mathrm{M}$ \\
\hline \multirow[t]{2}{*}{ balloon } & 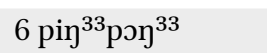 & $\mathrm{G1F}, \mathrm{G} 2 \mathrm{~F}, \mathrm{G}_{2} \mathrm{M},{ }_{3} \mathrm{G}_{3} \mathrm{~F}$ \\
\hline & 5 unknown & ${ }_{3} \mathrm{G1F}, \mathrm{G1M}, \mathrm{G}_{2} \mathrm{M}$ \\
\hline
\end{tabular}

\section{Discussion}

Selinker (1992) categorized lexical changes in language contact situations. Terms can be classified as expansive (a new word fills a gap in the lexicon), additive (new and old terms are both used), replacive (the former word disappears), loan shift (an old word's meaning changes to fill a lexical gap), loan translation (new words or phrases are translated literally), or loan blend (the term combines words or parts of words from multiple languages) 
(Selinker 1992: 46). The data in Tables 3.2 and 3.3 provide evidence for expansive, additive, replacive, and loan blend loanwords in Cambodian Teochew.

Expansive vocabulary would be terms for local dishes like 'papaya salad', 'Cambodian crepe', 'prahok', 'kralan', 'amok', and 'lok lak' that likely did not exist in the language of the historic Teochew settlers in Cambodia. The Khmer word may have been adopted out of necessity and/or convenience. 'Papaya salad', 'Cambodian crepe', 'prahok', 'amok', and 'lok lak' were strongly attested in the data (by nine or more speakers), and no other words were provided as alternatives to the Khmer loanword. The evidence was not as strong for 'kralan', a dish made of sticky rice inside bamboo. Only three speakers $\left(\mathrm{G}_{1}, 2 \mathrm{G}_{3}\right)$ said the Khmer loanword $\mathrm{ka}^{33} \mathrm{la \eta}^{33}$. Two speakers $\left(\mathrm{G}_{2}, \mathrm{G}_{3}\right)$ did not know a Teochew word for it and two $(\mathrm{G} 1, \mathrm{G} 2)$, said $t e k^{2-5} \mathrm{~kJ}^{33} \mathrm{kue}^{52}$ 竹管粿 which translates to 'bamboo cake'. The use of this word suggests that historic settlers in Cambodia came across 'kralan' and created a new word for it using terms already present in their Teochew like $t e k^{2}$ 竹 'bamboo' and $k u e^{52}$ 粿 'cake', rather than adopting the Khmer term. ${ }^{9}$

Other potentially expansive vocabulary items include the tropical fruits 'rambutan' and 'mangosteen'. The English word 'rambutan' is itself a loanword from Malay rambutan. This fruit is often red in colour with hair-like protuberances. Singapore Teochew's $a \eta^{55} \mathrm{mo}^{55} \mathrm{ta \eta}^{33}$ (Goh 2017: 205) (and Mandarin's $h o \eta^{35} \mathrm{mao}^{35} \tan ^{55}$ 红毛丹) was created with phono-semantic matching (see Ding, this volume); $a \eta^{55} \mathrm{mo}^{55}$ 'red hair' describes the appearance of the fruit and the $\operatorname{ta\eta }^{33}$ is a phonetic matching of the final syllable of the Malay word (where $/ \mathrm{n} /$ is pronounced $/ \mathrm{y} /$ due to Teochew phonotactics). Similarly, 'mangosteen' comes from Malay maygis. Singapore Teochew has again used phono-semantic matching with the Malay word in $\mathrm{ma \eta}^{55} \mathrm{hek}^{1}$ 芒黑 (Goh 2017: 209), where $m a \eta^{55}$ matches the source word's pronunciation and hek 'black, dark' describes the fruit's outer colour. It is not known if the early Teochew settlers to Cambodia had words for 'rambutan' or 'mangosteen'. If they did and adopted the Khmer loanwords $s a u^{33} m a u^{33}$ and $m a \eta^{11} k^{h} u{ }^{2}$ (each used by ten speakers in this study), these would be examples of replacive borrowing. If terms did not exist, they would be additional cases of expansive borrowing.

Food items such as 'avocado' and 'ice cream' are also likely expansive loanwords, though these are not native to Khmer cuisine. No word was found for 'avocado' in the historical sources. It is likely a new food item introduced after Teochew speakers had arrived in Cambodia. The Khmer loanword $b w^{33}$, attested in four speakers $\left({ }_{3} \mathrm{G}_{1}, \mathrm{G}_{3}\right)$, was likely adopted out of efficiency. Alternate words include $g u^{55-11} n i^{11} k u e^{52}$ 牛奶果 ('milk fruit') used by

9 Thus $t e k^{2-5} \mathrm{kJ \eta}^{33} k u e^{52}$ is also an example of an expansive vocabulary item. 
one G3 speaker, and $g u^{55-11} i u^{55-11} k u e^{52}$ 牛油果 ('butter fruit') used by one G2 speaker. In these cases, existing Teochew words were put together to create the new word 'avocado'.10 The Khmer word 'ice cream' ka:resm is borrowed from French crème. Since the Cambodian Teochew form $\mathrm{ka}^{11} \mathrm{lem}^{33}$ so closely resembles the Khmer pronunciation, it was determined that the Khmer form likely influenced its pronunciation in the language of interest. Seven speakers in this study used this borrowed form. Alternatively, one speaker said sio ${ }^{2-5} \mathrm{k}^{33}$ 雪糕 which translates literally to 'snow cake'. In contrast, Singapore Teochew uses the loanword $a i^{33} \mathrm{~s}^{33}{ }^{3} \mathrm{kik}^{1} \mathrm{lim}^{55}$ 爱士吉林 from English 'ice cream' (Goh 2017: 205).

The data provided evidence of additive loanwords in Cambodian Teochew, e.g. the word for 'jungle, forest'. Dean (1841) is the only historical source with a word glossed as 'jungle', while Duffus (1883) and Fielde (1883) have words listed under 'forest'. Either way, Cambodian Teochew speakers seemingly chose to adopt the Khmer word for 'jungle, forest' in $\left.p v^{33}\right\lrcorner i^{52}$, used by eight speakers in this study. Per Haspelmath (2009: 49), "lexical meanings do not have to fit into predefined slots". Potentially the historic Teochew words for 'forest' were not sufficient to describe the wooded areas in Cambodia. Consultants were shown several pictures at different times of various types of wooded areas in an attempt to disconcert a difference between 'forest' and 'jungle'. Evidence points to some usage of historic Teochew terms, in addition to the adoption of a Khmer loanword. As Table 3.3 shows, one speaker (G1) used both $p v^{33} h i^{52}$ and the historic $t_{6}{ }^{h}{ }^{1}{ }^{11}{ }^{1} i^{55}$, while one speaker (G1) used solely the latter term. Two G3 speakers never produced a Teochew word for 'jungle' or 'forest', which hints at its rarer usage in Cambodia. ${ }^{11}$ Khmer prei ị̂ต 'forest' has metaphorical importance in Cambodian culture (see Edwards 2008 and Lim 2011), so it is perhaps for this reason that the Cambodian Teochew have adopted the Khmer word into their language. $\mathrm{Lim}^{55}$ 林 'forest' is the second most common surname in the Chaoshan region, held by over 1 million people (The Teochew Store). This is perhaps why the historic Teochew word has not been eschewed altogether.

$10 g u^{55-11} i u^{55-11} k u e^{52}$ 牛油果 'butter fruit' could also be a loan translation from Khmer $p^{h}$ lasbə، 'fruit-butter'.

11 Singapore Teochew speakers also had difficulty producing a word for 'forest' in Ho's (2009) study on vocabulary retention in younger speakers. Ho (2009) found that words related to nature including 'forest', 'lake', and 'fog' were commonly missing in the vocabulary of the speakers in the study. My data provides evidence that this may also be the case for some speakers in Cambodian Teochew. In addition to 'forest' which was explained above, one $\mathrm{G}_{3}$ speaker used a loanword $b a \eta^{33}$ 'lake' from Khmer 6 3 $\eta$ ธึน (versus historic Teochew $u^{55}$ 湖 used by three speakers, ${ }_{2} \mathrm{G}_{3} \mathrm{~F}, \mathrm{G1F}$ ). Meanwhile, the two other $\mathrm{G}_{3}$ speakers used a loanword $a p^{5}$ for 'fog' from Khmer Pap รัฒূ (versus historic Teochew terms $m \eta^{55}$ 蒙, $m o u^{55}$ 零, and $b u^{11}$ 雾 $\mathrm{used}$ by $\mathrm{GIF}, \mathrm{GIF}$, and $\mathrm{G}_{3} \mathrm{~F}$ respectively). 
Cambodian Teochew $p i^{33}$ 'from', which comes from Khmer $p i$ : $ี$, is the one example of the borrowing of a function word. ${ }^{12}$ Generally, we can see $t a \eta^{11}$ 'from' used in time expressions in Singapore Teochew (5a) and historical Teochew (5b), and in locative expressions in historical Teochew in (6).

5) a. $\mathrm{a}^{33}-Z a c h \quad \operatorname{ta\eta }^{11} \quad \mathrm{sji}^{213} \quad \operatorname{tsu}^{11} \operatorname{tsin}^{33} \operatorname{tsĩa}^{11} \operatorname{gau}^{11}$ pua $^{2}$ lai ${ }^{55}$ NVOC-PN from young SEQ very good.at fall come pua $^{2} \quad \mathrm{khi}^{11}$

fall go

'From a young age, Zach was very accident-prone.' (Low 2014: 54)

b. $\tan ^{11} \quad \operatorname{ts}^{\mathrm{h}} \mathrm{u}^{2} \mathrm{si}^{313} \quad \mathrm{kau}^{313} \quad \mathrm{ta}^{33}$

from birth arrive now

'from his birth till now' (Fielde 1878: 172)

6) $\tan ^{11} \quad \operatorname{tsi}^{53} \quad \operatorname{siã}^{55} \quad \mathrm{kau}^{313} \quad \operatorname{nin}^{53} \quad \mathrm{tse}^{11} \quad \mathrm{lai}^{25} \quad \mathrm{u}^{25}$

from this city arrive $2 \mathrm{PL}$ village there is

dzier $^{255}$ tsoi $^{25} \quad \mathrm{li}^{53} \quad \mathrm{lo}^{25}$

how much distance

'How far is it from this city to your village?' (Fielde 1878: 240)

In Khmer, pi: 'from' is also used with locative (7) and time (8) expressions.

7) mosk pi: srok Pạkleeh

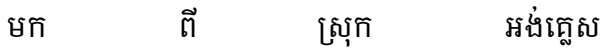

come from country England

'(She) comes from England.' (Sak-Humphry 2015:5)

8) cap pi: moay pram kanlah rohootdal moay dap yup

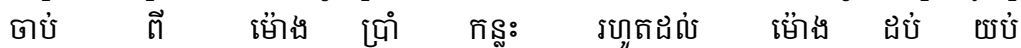
starting from hour five half until hour ten night 'starting from 5:3OPM until 10:OOPM' (Sak-Humphry 2015: 50)

There is evidence that loanword $p i^{33}$ 'from' in Cambodian Teochew is similarly used with both locative (9) and time expressions (10).

12 Function words are generally less borrowable than content words (Tadmor 2009). There is evidence of other function words borrowed in Teochew varieties in the region including itu 'this' and relativizer yang in Indonesian Teochew (Peng 2012) and $t a^{33} \mathrm{pI}^{25}$ 'but' in Singapore Teochew (Yeo 2012), all borrowed from Malay. 


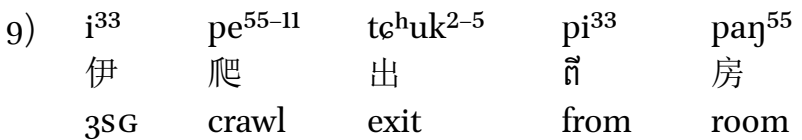

'He crawled out from his room.'

\begin{tabular}{|c|c|c|c|c|c|}
\hline $\mathrm{pi}^{33}$ & $\mathrm{ik}^{2-5}$ & $\operatorname{tiam}^{52}$ & $\mathrm{kau}^{11-53}$ & $\eta^{\prime} u^{24-11}$ & tiam $^{52}$ \\
\hline ตี & 一 & 点 & 到 & 五 & 点 \\
\hline from & one & o'clock & arrive & five & o'clock \\
\hline
\end{tabular}

'from 1 o'clock to 5 o'clock'

Evidence shows that Cambodian Teochew has replacive borrowings in 'papaya' and 'balloon'. The word $b a k^{5} k u e^{33}$ 木瓜 'papaya' was found in Fielde (1883: 277) and in Indonesian and Singapore Teochew varieties. No evidence was found for the existence of $b a k^{5} k u e^{33}$ in Cambodian Teochew. Conversely, $10^{11} h \ni \eta^{55}$ 'papaya' was used by ten speakers in this study. The author suggests that the use of the Khmer-origin word comes as an extension of the loanword for the popular 'papaya salad' dish, $b{ }^{2}{ }^{2} b^{11} h o \eta^{55}$. Since the Cambodian Teochew were already using $l^{11} h \eta^{55}$ for this dish's name, it would be more efficient to refer to the fruit 'papaya' using the same word. Duffus (1883:17) presented several words for 'balloon' including $p^{h} u^{55}-h u n^{55}-k i u^{55}, t^{h} i \varepsilon n^{33}-t s u n^{55}$, and $k^{h} i^{313}-k i u^{55}$. Each of these words has the morpheme kiu $u^{55}$ 球 'ball'. Per Weinreich (1979), relatively infrequent vocabulary items are more likely candidates for replacement. This may be the case with 'balloon' and so the Khmer word was adopted out of convenience. The Khmer loanword was attested by six speakers $\left(\mathrm{G}_{1}, 2 \mathrm{G} 2,3 \mathrm{G}_{3}\right)$ and no evidence was found for the use of historic Teochew words. Singapore Teochew has also adopted a loanword $b e^{33} l o \eta^{55}$ 码隆 from English (Goh 2017: 206).

Finally, Cambodian Teochew has one loan blend in 'to give a gift'. This is a hybrid Teochew-Khmer phrase in which the verb 'give' is pronounced as Teochew $h o u^{11}$ 互, while the noun 'gift' $k a^{11} d o u^{11}$ comes from Khmer kadov กก ข้ 'gift'; $h \supset u^{11} k a^{11} d o u^{11}$ is specifically used to mean to give someone a gift or present. No evidence was found of $k a^{11} d o u^{11}$ being used in other contexts and it always appeared with hou ${ }^{11}$. The three $\mathrm{G}_{3}$ speakers in this study used this phrase. The picture shown to consultants was an extended hand with a box with a bow. Speaker responses to this cue varied. Two speakers said solely $h o u^{11}$ when shown the prompt; $h \supset u^{11}$ 'to give' is used in Cambodian Teochew in phrases such as 'to give money' or 'to give plants'. Five speakers used a phrase with $s a \eta^{53}$ 送, which means 'to gift'. ${ }^{13}$ Two speakers said $s a \eta^{53} l o i^{52}$ 送礼 'to give

13 Citation tone for this word in Cambodian Teochew is unconfirmed. 


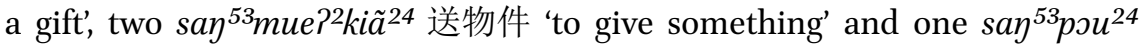
送簿 'to gift a book'. Given that it was the younger speakers who used the loan blend, it could be a relatively new word adaptation in Cambodian Teochew. More evidence is needed to verify this claim.

\section{Concluding Remarks}

This section discusses some limitations to the current study and summarize its findings and implications, while also providing directions for future research. The fifteen words found in this chapter and presented in Table 3.2 do not constitute an exhaustive list of Cambodian Teochew's Khmer loanwords. More examples might surface with additional fieldwork and data analysis. Because the methodology relied on elicitation using wordlists, and descriptions of fairly simple pictorial stories, the collected vocabulary items are limited. There are likely many more words that are beyond the categories this current study has covered. ${ }^{14}$

Furthermore, given the relatively few speakers consulted for this project, and other reasons outlined below, it is impossible to generalize about Cambodian Teochew as a whole and this chapter attempted to only present findings based on the collected data. Variation existed even amongst the eleven consultants, as shown in Table 3.3, so more variation would likely be found in a larger sample size. Because seven speakers in this project were related, though they were living in four different households, there was the potential that the data would show the Teochew spoken by only one family. Attempts made to diversify participants by recruiting from online spaces succeeded in bringing in an additional four speakers, all from separate families. Yet the online recruiting process itself likely influenced the type of speakers integrated in this project. Online spaces included Facebook group Gaginang where interactions are primarily conducted in English, and the Cambodian Teochew Association's Facebook page which is primarily conducted in Mandarin. Someone not speaking one of those languages, or someone not on Facebook, may not have been a participant in one of those spaces, thus making it challenging for them to be included in this study. However, one speaker found through this method was not a participant herself, and instead was introduced to me through her grandchildren. As for the three other speakers recruited on Facebook, it is

14 For example, Teo (1993) found the Peranakan Chinese in Malaysia to use loanwords in areas such as diseases and illnesses, adjectives, and more rarely used nouns and verbs such as 'affair', 'curfew', 'sue', and 'assassinate', among others. 
possible that their Teochew had degraded due to their use of other languages and thus their usage of loanwords from Khmer may be different from the general population. Additionally, all speakers interviewed were from Phnom Penh so there is no data on loanword usage by Cambodian Teochews living outside the capital city. This study could be expanded upon by working with more speakers with a broader set of picture prompts and stories and re-interviewing speakers from early consultations in order to check their loanword usages.

Challenges in the interview process have also affected data collection. First, there is the case of the observer's paradox in that my presence in the interviews would have affected the speakers' responses. For example, it may have been the case that speakers knew both a Khmer loanword and a historic Teochew word for a prompt, and even if they use the loanword more often in daily speech, they may have said the Teochew word in the interview because they knew my research was on that language. Furthermore, six interviews were conducted with the use of family members as interpreters which did not give me the same control as the interviews conducted solely by the researcher in English. Picture prompts were used in all interviews in order to reduce the effects of second language interference. Yet sometimes the interpreters would still say the target word in Khmer or in Teochew. This may have affected the speakers' responses. The consultant may have been more likely to say a Khmer loanword due to a Khmer prime, and their word choice may have similarly been affected if given a Teochew prime.

Fourteen of the fifteen words in Table 3.2 are content words versus function words and these fourteen are all nouns rather than verbs. This aligns with the findings from the Loanword Typology Project (Tadmor 2009). Furthermore, the loanwords suggest that lexical borrowing in Cambodian Teochew is primarily cultural. ${ }^{15}$ However, Cambodian Teochew seems resistant to lexical changes overall. In comparison, Goh (2017) identifies over 200 foreign language loanwords in Singapore. The sociolinguistic situation in Singapore is very different from Cambodia, with that Teochew variety coming into contact with English, Hokkien, Malay, Mandarin, Tamil, and others, all of which are source languages for words on Goh's list. A likely contributing factor to the relatively few Khmer loanwords in Cambodian Teochew is the fact that many Khmer terms already resembled Teochew words, as explored in section 2. Thus staple foods like $m i$ 面 'noodles' and kûe tíaw 粿条 'noodle soup' sound very similar

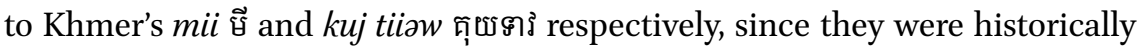
borrowed from Teochew (Pou \& Jenner 1973). Even still, Thai similarly has

15 As opposed to core vocabulary (cf. Myers-Scotton 1993; Haspelmath 2009). 
borrowed extensively from Teochew or other Sinitic varieties and Lin (2006) found over 6o Thai loanwords in the Teochew spoken in Thailand. Thus the findings in this chapter speak volumes to the Cambodian Teochews' determination to maintain their language and resist lexical changes, despite constant linguistic pressure from the dominant Khmer language.

\section{References}

Ashmore, William, Primary Lessons in Swatow Grammar (English Presbyterian Mission Press, 1884).

Atchariyasucha, Wichet, A Phonological study of Swatow of Chinese as spoken in Bangkok with comparisons to Thai (MA thesis, Mahidol University, Mahidol University Library and Knowledge Center, 1982). http://mulinet11.li.mahidol.ac.th/e-thesis/ scan/1405o.pdf.

Aw, Tash, 'Coming out of the shadows: what it means to be French and Chinese', The Guardian (2019, November 26). https://www.theguardian.com/world/2019/nov/26/ what-you-hear-about-chinese-people-in-france-feeling-scared-its-true.

Bao, Zhiming, 'Tonal contour and register harmony in Chaozhou', Linguistic Inquiry, 30/3 (1999): 485-93.

Birnie-Smith, Jessica Rae, 'Ethnic identity and language choice across online forums', International Journal of Multilingualism, 13/2 (2016):165-83. https://doi.org/10.1080/ 14790718.2015.1078806.

Bourgerie, Dana Scott, 'Education in the Cambodian Chinese diaspora', in O.E. Kagan, M.M. Carreira and C.H. Chik (eds.), The Routledge Handbook of Heritage Language Education: From Innovation to Program Building (London: Routledge, 2017): 161-78. https://doi.org/10.4324/9781315727974-13.

Chan, Sambath, The Chinese minority in Cambodia: Identity construction and contestation (MA thesis, Concordia University, 2005). https://spectrum.library.concordia .ca/8439/.

Chen, Shihlun Allen, Socializing Chineseness: Cambodia's ethnic Chinese communities as a method ( $\mathrm{PhD}$ dissertation, University of Hawai'i at Manoa, publication number 10002238, 2015).

Chen, Xiaojin, "陈晓锦, 越南、柬埔寨、老挝三国潮州话训读现象比较 Comparative study on xundu phenomenon of Chaozhou dialect in Vietnam, Cambodia and Laos', 广东技术师范学院学报, 4 (2009): 79-84.

Chin, James K., 'Ethnicized networks and local embeddedness: The new Chinese migrant community in Cambodia', in M. Zhou (ed.), Contemporary Chinese diasporas (Berlin: Springer, 2017): 187-206. https://doi.org/10.1007/978-981-10-5595-9_9. 
Chokkajitsumpun, Pranee, Chinese literacy maintenance and shift in Bangkok: Individual and family cases (unpublished $\mathrm{PhD}$ dissertation, University of Hawai'i at Mānoa, 1998).

Clayton, Thomas, Language choice in a nation under transition: English language spread in Cambodia (Berlin: Springer, 2006). https://doi.org/10.1007/0-387-31194-7.

Cole, Peter, Hermon, Gabriella and Lee, Cher Leng, 'Grammatical and discourse conditions on long distance reflexives in two Chinese dialects', in P. Cole, G. Hermon and C.-T.J. Huang (eds.), Long distance reflexives (Leiden: Brill, 2000): 1-46. https://doi .org/10.1163/9781849508742_oo2.

Cole, Peter and Lee, Cher Leng, 'Locality constraints on yes/no questions in Singapore Teochew', Journal of East Asian Linguistics, 6/2 (1997): 189-211. https://doi.org/10 .1023/A:1008237705178.

Cooper, Doug, Notes on Modern Chinese loanwords in Thai, 2020. Retrieved June 1 from http://sealang.net/thai/chinese/modern.htm.

Dean, William, First lessons in the Tie-chiw dialect (Bangkok: Siam, 1841).

Dorais, Louis-Jacques, 'Refugee adaptation and community structure: The Indochinese in Quebec City, Canada', International Migration Review, 25/3 (1991): 551-73. https:// doi.org/10.1177/019791839102500305.

Duffus, William, English-Chinese vocabulary of the vernacular or spoken language of Swatow (Swatow: English Presbyterian Mission Press, 1883).

Edwards, Penny, 'Between a song and a prei: Tracking Cambodian history and cosmology through the forest', in A.R. Hansen and J. Ledgerwood (eds.), At the edge of the forest: Essays on Cambodia, history, and narrative in honor of David Chandler (Ithaca: Cornell University Press, 2008): 137-62.

Edwards, Penny, 'Ethnic Chinese in Cambodia', in Ethnic groups in Cambodia (Phnom Penh: Center for Advanced Study, 2009): 174-234.

Edwards, Penny, 'Addendum to the introduction: New directions', Cross-Currents: East Asian History and Culture Review, 1/2 (2012): 274-78. https://doi.org/10.1353/ ach.2012.0013.

Egerod, Søren, 'Swatow loan words in Siamese', Acta Orientalia, 23 (1958): 137-56.

Eiampailin, Janida, The phonological interference of Swatow in Standard Thai by Chinese speakers in Bangkok (MA thesis, Mahidol University, 2004).

Fielde, Adele Marion, First lessons in the Swatow dialect (Swatow: Swatow Printing Office Company, 1878).

Fielde, Adele Marion, A pronouncing and defining dictionary of the Swatow dialect: Arranged according to syllables and tones (Swatow: American Presbyterian Mission Press, 1883).

Filippi, Jean-Michel, 'Cambodia: The swing of the pendulum', Phnom Penh Post, 26 November 2010. https://www.phnompenhpost.com/post-plus/cambodia-swing -pendulum. 
Filippi, Jean-Michel and Hiep, Chan Vicheth, Khmer pronouncing dictionary: Standard Khmer and Phnom Penh dialect (KAM, UNESCO, 2016). https://www.publikam.com/ en/pages/bookstore-3.html.

Fishman, Joshua A., Reversing language shift: Theoretical and empirical foundations of assistance to threatened languages (Bristol: Multilingual Matters, 1991).

Giles, Herbert Allen, Handbook of the Swatow dialect: With a vocabulary (published with the assistance of the Straits' Government, 1877).

Goddard, Josiah, A Chinese and English vocabulary, in the Tie-chiu dialect (2nd edn., Swatow: American Presbyterian Mission Press, 1888).

Goh, Eng Choon 吴英俊, 潮州口语 Colloquial Teochew (Singapore: NETUCC, 2017).

Goh, Rui Long 吴获珑, 端华学校: 柬埔寨华文教育的案例 Duan Hua (Toun Fa) Chinese school: A case of Chinese education in Cambodia (final year project, Nanyang Technological University, 2011). Digital Repository of NTU. http://hdl.handle. net/10356/43682.

Gong, Gunhu, A list of Swatow loanwords in Thai (unpublished PhD dissertation, Shantou University, 2000).

Gyarunsut, Pranee ปราณี กาย อรุณ สิทธิ์, คำ ยืม ภาษา จีน ใน ภาษา ไทย ปัจจุบัน Chinese loanwords in modern Thai (MA thesis, Chulalongkorn University, 1983). Chulalongkong University Intellectual Repository. http://cuir.car.chula.ac.th/handle/ 123456789/37061.

Haspelmath, Martin, 'Lexical borrowing: Concepts and issues', in M. Haspelmath and U. Tadmor (eds.), Loanwords in the world's languages: A comparative handbook (Berlin: De Gruyter Mouton, 2009): 35-54. https://doi.org/10.1515/9783110218442.35. Ho, Pei Qin 何佩芩, 语言的消亡: 以新加坡潮州话为个案: 兼论基本词汇的有阶分布 Language decline: a case study on Singapore Teochew dialect and a study of the rank theory in basic word list (final year project, Nanyang Technological University, 20o9). Digital Repository of NTU. https://hdl.handle.net/10356/14980.

Hong, Ying, A phonetic study of Chaozhou Chinese (PhD thesis, Hong Kong University of Science and Technology, 2013). HKUST SPD: The Institutional Repository. http:// hdl.handle.net/1783.1/623o8.

Huang, Yu 黄瑜 and Mo, Yuan-Yuan 莫源源, “柬埔寨语中汉借词的语音特征分析 Phonological features of Chinese loanwords in Khmer, 课程教育研究 Course Education Research, 21 (2017): 95-97.

Huffman, Franklin Eugene, 'An outline of Cambodian grammar' (PhD thesis, Cornell University, 1967; publication number 6717239).

Kang, Yoonjung, 'Loanword phonology', in M. van Oostendorp, C.J. Ewen, E.V. Hume and K. Rice (eds.), The Blackwell companion to phonology (Hoboken: John Wiley, 2011): 1-25. https://doi.org/10.1002/9781444335262.wbctpoo95.

Khoo, Kiak Uei 邱克威, ‘来西亚雪兰莪洲滨海潮州渔村澄海人方言音系比较分析 A comparative phonological study of Chenghai dialects of Teochew fishing villages 
in Selangor Malaysia', 马来亚大学华人文学与文化学刊第五卷 Journal of Chinese Literature and Culture, 5/1 (2017a): 14-24. https://ejournal.um.edu.my/index.php/ JCLC/article/view/17465.

Khoo, Kiak Uei 邱克威, ‘马来西亚汉语方言声调变异及其社会因素的调查研究: 以霹 䨌州北部三个相邻渔村的普宁话为个案分析 Survey on the Malaysian Chinese dialect tonal variations and its social influences: Case study on Chaozhou (Puning) dialect of three neighbouring fishing villages in North Perak, 海外华文教育 Overseas Chinese Education, 2 (2017b): 258-67.

Khoo, Kiak Uei 邱克威, 馬來西亞巴冬潮汕話陰上調的方言融合與條件變讀 Dialect mixing and conditioned variants in Yin Shang tone of Chaoshan dialects in Parit Jawa fishing village of Malaysia, 臺灣語文研究, 13/2 (2018): 201-12. https://doi .org/10.6710/JTLL.201810_13(2).0002.

Kyne, Phelim, 'Cambodia's middle kingdom: Chinese schools, back from the brink', Phnom Penh Post, 25 June 1999. https://www.phnompenhpost.com/national/chinese -schools-back-brink.

Lee, Cher Leng, 'Grandmother's tongue: Decline of Teochew language in Singapore.' in W. Li (ed.), Multilingualism in the Chinese diaspora worldwide: Transnational connections and local social realities (London: Routledge, 2015): 196-215. https://doi .org/10.4324/9781315759371.

Lee, Hugo Yu-Hsiu, 'Losing Chinese as the first language in Thailand', Asian Social Science, 10/6 (2014): 176-93. https://doi.org/10.5539/ass.vion6p176.

Li, Danni, Acoustic analysis of the tones in the Shantou dialect (MA thesis, University of Massachusetts Amherst, 2014). ScholarWorks@UMass Amherst. https://scholarworks.umass.edu/masters_theses_2/29.

Li, Wei, Saravanan, Vanithamani and Ng, Julia Lee Hoon, 'Language shift in the Teochew community in Singapore: A family domain analysis', Journal of Multilingual and Multicultural Development, 18/5 (1997): 364-84. https://doi.org/10 $.1080 / 01434639708666326$.

Li, Yongming 李永明, 潮州方言 Chaozhou dialect (Hong Kong: 中華書局, 1959).

$\mathrm{Li}$, Yongming 李永明, ‘新加坡潮州话的外语借词和特殊词语 Loanwords and special words in Singapore Teochew', 方言, 7 (1991): 56-63.

Lim, Alvin Cheng-Hin, Desiring Cambodia (unpublished PhD dissertation, University of Hawai'i at Mānoa, 2011).

Lim, Hiong Seng, Handbook of the Swatow vernacular (Singapore: Koh Yew Hean Press, 1886).

Lin, Lun-Lun 林伦伦, “潮汕方言声调研究 Research on the tones of Chaoshan dialect', 语文研究, 1 (1995), 52-9.

Lin, Lun-Lun 林伦伦, “澄海方言研究 Research on the Chenghai dialect.' (Shantou: 汕头 大学出版社, 1996). 
Lin, Lun-Lun 林伦伦, “潮汕方言和泰语的双向借词及其演变发展 Thai loanwords in Chaoshan dialect and Chaoshan dialect loanwords in Thai language', 民族語文, 2 (2006), 24-30.

Lin, Lun-Lun 林伦伦 and Chen, Zhao-Er 陈照儿, 外砂话声调与澄海话, 汕头话的比 较研究 Tones of Waisha dialect and its comparative study with Chenghai dialect and Shantou dialect', 汕头大学学报 (人文社会科学版) Shantou University Journal (Humanities \& Social Sciences Bimonthly), 27/3 (2011): 56-6o.

Lin, Qing, The diachrony of tone sandhi: Evidence from Southern Min Chinese (Berlin: Springer, 2019). https://doi.org/10.1007/978-981-13-1939-6.

Low, Elissa Jia Min, A sketch grammar of Singapore Teochew (final year project, Nanyang Technological University, 2014). Digital Repository of NTU. https://hdl .handle.net/10356/65807.

Ly, Y., Heaven becomes Hell: A survivor's story of life under the Khmer Rouge (ed. J.S. Driscoll, Yale University Southeast Asia Studies, 2000).

Manomaivibool, Prapin, A study of Sino-Thai lexical correspondences (PhD dissertation, University of Washington, 1975). ResearchWorks Archive. http://hdl.handle .net/1773/11132.

Matthews, Stephen, Xu, Huiling and Yip, Virginia, 'Passive and unaccusative in the Jieyang dialect of Chaozhou', Journal of East Asian Linguistics, 14/4 (2005): 267-98.

Matthews, Stephen and Yip, Virginia, 'Passive, unaccusative and pretransitive constructions in Chaozhou,' in R. Djamouri, B. Meisterernst and R. Sybesma (eds.), Chinese linguistics in Leipzig (漢語語言學在萊比錫) (EHESs, Centre de Recherches Linguistiques sur l'Asie Orientale, 2008): 163-74.

McFarland, Joanna R., A preliminary comparative analysis of Cambodian Teochew: Evidence for contact-induced change (unpublished MA dissertation, University of Hong Kong, 2017).

McFarland, Joanna R., A grammar of Cambodian Teochew (PhD dissertation, Nanyang Technological University, forthcoming).

Miao, Ruiqin, Loanword adaptation in Mandarin Chinese: Perceptual, phonological and sociolinguistic factors (PhD dissertation, Stony Brook University, 2005). RUcore: Rutgers University Community Repository. https://rucore.libraries.rutgers.edu/ rutgers-lib/38301/.

Morita, Liang, 'Discussing assimilation and language shift among the Chinese in Thailand, International journal of the sociology of language, 186 (2007): 43-58. https://doi.org/10.1515/IJSL.2007.041.

Myers-Scotton, Carol, Duelling languages: Grammatical structure in codeswitching (Oxford: Oxford University Press, 1993).

$\mathrm{Ng}$, Julia Lee Hoon, Language maintenance and language shift in the Teochew Chinese community (academic exercise, National Institute of Education, 1996). NIE Digital Repository. http://hdl.handle.net/10497/1723. 
Nyíri, Pál, 'Investors, managers, brokers, and culture workers: How the "new" Chinese are changing the meaning of Chineseness in Cambodia', Cross-Currents: East Asian History and Culture Review, 1/2 (2012):369-97. https://doi.org/10.1353/ach.2012.0012.

Nyíri, Pál, "New migrants" from the PRC and the transformation of Chinese media: The case of Cambodia', in W. Sun and J. Sinclair (eds.), Media and communication in the Chinese diaspora (London: Routledge, 2015): 15-31. https://doi.org/10.4324/ 9781315717265 .

Ong, Teresa Wai See, Language maintenance in Malaysia: A case study of the Chinese community in Penang (PhD thesis, Griffith University, 2018). Griffith Research Online. http://hdl.handle.net/10072/382738.

Pan, Jiayi 潘家懿, ‘柬埔寨第三代华人潮汕话记略 Cambodia’s third generation Chaoshan speakers', in R. Li (ed.), 东南亚华人语言研究 Studies of Chinese Languages in Southeast Asia (Beijing: 北京语言文化大学出版社 Beijing Language and Culture University Press, 2000).

Panh, Rithy and Bataille, Christophe, The elimination: A survivor of the Khmer Rouge confronts his past and the commandant of the killing fields (trans. J. Cullen, New York City: Other Press, 2012).

Peng, Anne Elise, 'Head-final and head-initial relative clauses in Jambi Teochew', in K. Otaki, H. Takeyasu and S.-I. Tanigawa (eds.), Online Proceedings of GLOW in Asia Workshop for Young Scholars (2011): 262-76. http://faculty.human.mie-u .ac.jp/ glow_mie/Workshop_Proceedings/2oPeng.pdf.

Peng, Anne Elise, Aspects of the syntax of Indonesian Teochew (unpublished PhD dissertation, University of Delaware, 2012).

Phadungsrisavas, Veerakit, An acoustical comparative study of Swatow Chinese tones spoken in five regions of Thailand (unpublished MA thesis, Mahidol University, 2008).

Pou, Saveros and Jenner, Philip N., 'Some Chinese loanwords in Khmer', Journal of Oriental Studies, 11/1 (1973): 1-9o.

Quek, Huan Ting Geraldine, Investigating language loss within Singapore's Teochew community (unpublished final year project, Nanyang Technological University, 2013).

Rappa, Antonio, Thailand's Chinese population: Teochiu speakers and political identity (unpublished paper, 2014).

Sak-Humphry, Chhany, Colloquial Cambodian: The complete course for beginners (new edn., London: Routledge, 2015). https://doi.org/10.4324/9780203120651.

San Roque, Lila, Gawne, Lauren, Hoenigman, Darja, Miller, Julia Colleen, Rumsey, Alan, Spronck, Stef, Carroll, Alice and Evans, Nicholas, 'Getting the story straight: Language fieldwork using a narrative problem-solving task', Language Documentation \& Conservation, 6 (2012): 135-74. http://hdl.handle.net/10125/4504. 
Schliesinger, Joachim, Ethnic groups of Cambodia, volume 3: Profile of Austro-Thai and Sinitic-speaking peoples, vol. 3 (Banglamung: White Lotus, 2011).

Selinker, Larry, Rediscovering interlanguage (London: Routledge, 1992). https://doi.org/ $10.4324 / 9781315845685$.

Shih Shu-mei, 'Introduction: What Is Sinophone Studies?', in Shih Shu-mei, ChienHsin Tsai and Brian Bernards (eds.), Sinophone Studies: A Critical Reader (New York: Columbia University Press, 2013): 1-16.

Sim, Tze Wei, 'Why are the native languages of the Chinese Malaysians in decline', Journal of Taiwanese Vernacular, 4/1 (2012): 62-95.

Siphat, Touch, 'Chinese capitalism in Cambodian sociopolitical contexts: The role of ethnic Chinese in the Cambodian economy,' in Y. Santasombat (ed.), Chinese capitalism in Southeast Asia (London: Palgrave Macmillan, 2017): 181-205. https://doi .org/10.1007/978-981-10-4696-4.

Stenberg, Josh, 'Multilingualism and the West Kalimantan Hakka,' in Li Wei (ed.), Multilingualism in the Chinese diaspora worldwide: Transnational connections and local social realities (London: Routledge, 2015): 123-40. https://doi.org/10.4324/ 9781315759371.

Stevens, Christine Audrey, "New life in the freedom country": Young Cambodians in Adelaide (PhD thesis, University of Adelaide, 1990). Adelaide Research \& Scholarship. http://hdl.handle.net/2440/19370.

Swadesh, Morris, 'Towards greater accuracy in lexicostatistic dating', International journal of American linguistics, 21/2 (1955): 121-37. https://doi.org/10.1086/464321.

Tadmor, Uri, 'Loanwords in the world's languages: Findings and results', in M. Haspelmath and U. Tadmor (eds.), Loanwords in the world's languages: A comparative handbook (Berlin: De Gruyter Mouton, 2009): 55-75. https://doi.org/10.1515/978311 O218442.55.

Tan, Danielle, La diaspora chinoise du Cambodge: Histoire d'une identité recomposée (unpublished MA thesis, Institut d'Etudes Politiques de Paris, 2006).

TCKnow LLC., WhatTCSay (Version 1.30) [Mobile app], 2015. App Store. https://apps .apple.com/us/app/whattcsay/id55089o8o2.

Tea, Van and Nov, Sokmady, 'The ethnic Chinese in Cambodia: Social integration and renaissance of identity, in Ethnic Groups in Cambodia (Phnom Penh: Center for Advanced Study, 2009): 235-80.

Teo, Kok, A sociolinguistic description of the Peranakan Chinese of Kelantan, Malaysia (PhD dissertation, University of California, Berkeley, 1993). eScholarship. https:// escholarship.org/uc/item/2hdgmg2j.

The Teochew Store, Top 100 surnames in Teochew (accessed 27 March 2016). https:// www.theteochewstore.org/blogs/latest/4069o499-top-10o-surnames-in-teochew -updated-27-march-2016. 
Ung, Loung, First they killed my father: A daughter of Cambodia remembers (Phnom Penh: Random House, 2017).

Veniranda, Yohana, Perfective aspect and negation in Pontianak Teochew (PhD dissertation, University of Delaware, 2015). University of Delaware Library Institutional Repository. http://udspace.udel.edu/handle/19716/17687.

Veniranda, Yohana, 'Oral and nasal vowels in Pontianak Teochew', LLT Journal: A Journal on Language and Language Teaching, 18/2 (2016): 107-24.

Verver, Michiel, "Templates of "Chineseness" and trajectories of Cambodian Chinese entrepreneurship in Phnom Penh', Cross-Currents: East Asian History and Culture Review, 1/2 (2012): 291-322. https://doi.org/10.1353/ach.2012.0017.

Verver, Michiel and Koning, Juliette, 'Toward a kinship perspective on entrepreneurship', Entrepreneurship Theory and Practice, 42/4 (2018): 631-66. https://doi .org/10.1177/1042258718783431.

Wang, Xiaomei, Mandarin spread in Malaysia (Kuala Lumpur: University of Malaya Press, 2012).

Wang, Xiaomei, 'The Chinese language in the Asian diaspora: A Malaysian experience', in G. Leitner, A. Hashim and H.-G. Wolf (eds.), Communicating with Asia: The future of English as a global language (Cambridge: Cambridge University Press, 2016): 205-15. https://doi.org/10.1017/CBO9781107477186.o14.

Weinreich, Uriel, Languages in contact: Findings and problems (Berlin: De Gruyter Mouton, 1979). https://doi.org/10.1515/9783110802177.

Willmott, William E., The Chinese in Cambodia (Vancouver: University of British Columbia Press, 1967).

Willmott, William E., 'Cambodia', in L. Pan (ed.), The Encyclopedia of the Chinese Overseas (2nd ed., Singapore: Editions Didier Millet, 2006): 144-50.

$\mathrm{Xu}$, Huiling, Aspect of Chaozhou grammar: A synchronic description of the Jieyang variety (Journal of Chinese Linguistics Monograph Series 22, 2007).

$\mathrm{Xu}$, Huiling and Matthews, Stephen, 'On the polyfunctionality and grammaticalization of the morpheme kai in the Chaozhou dialect,' in F.H. Yap, K. Grunow-Hårsta and J. Wrona (eds.), Nominalization in Asian Languages: Diachronic and typological perspectives (Amsterdam: John Benjamins, 2011): 109-24. https://doi.org/10.1075/ tsl.96.o3xu.

$\mathrm{Xu}$, Huiling and Matthews, Stephen, 'On the semantic continuum of the causative constructions in Chaozhou and Taiwanese Southern Min', in Overseas diaspora and homeland culture: proceedings of selected works of the ninth International Chaozhou Studies Symposium (Guangdong: Huacheng Publishing House, 2013): 232-44.

$\mathrm{Xu}$, Yuhang 徐宇航, “潮州方言百余年来韵母演变的研究 Phonological changes of vowels in Chaozhou dialect: From mid-nineteenth to early twenty-first century', 语言学论丛, 53 (2016): 241-6o. 
Yeo, Pamela Yu Hui, A sketch grammar of Singapore Teochew (final year project, Nanyang Technological University, 2011). Digital Repository of NTU. https://hdl .handle.net/10356/93949.

Zhou, Daguan, A record of Cambodia: The land and its people (trans. P. Harris, Chiang Mai: Silkworm Books, 2007). 